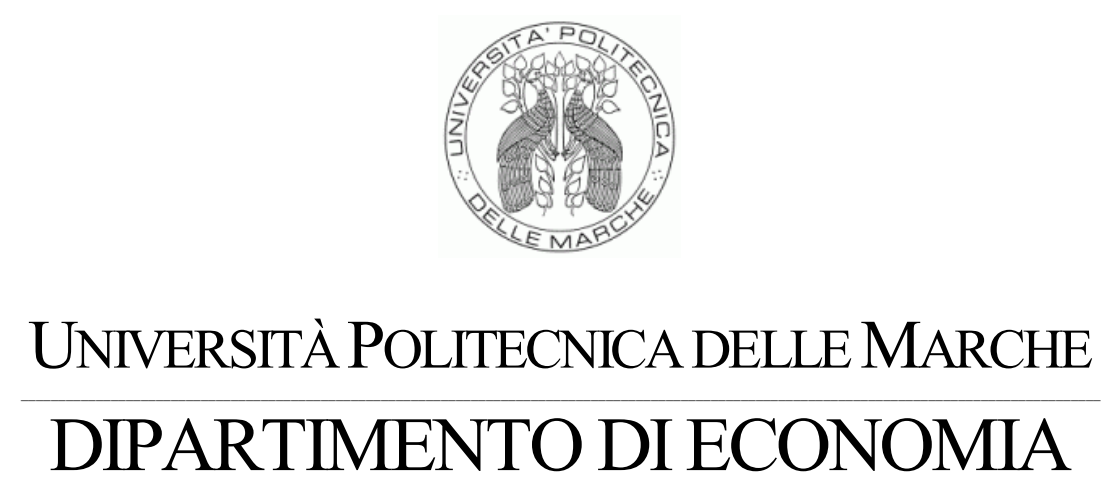

The Debt-Growth Nexus: a Dynamic

Panel Data Estimation

\author{
ANDREA F. PRESBITERO \\ QUADERNO DI RICERCA n. 243
}


Comitato scientifico:

Renato Balducci

Marco Crivellini

Marco Gallegati

Alberto Niccoli

Alberto Zazzaro

Collana curata da:

Massimo Tamberi 


\title{
The Debt-Growth Nexus: a Dynamic Panel
}

\author{
Data Estimation
}

\author{
Andrea F. Presbitero ${ }^{1}$
}

\begin{abstract}
This paper investigates the relationship between external debt and economic growth in poor countries. The adverse effects of external debt on economic performance are due to the crowding out of public investment and to the disincentive effects, because of debt overhang and uncertainty. Notwithstanding a general agreement on theory, empirical evidence is not conclusive and lacks of robustness. This contribution aims to shed more light on the relationship between external debt and economic growth and to draw some policy implication for debt relief. This work highlights the critical role of econometric and methodological issues. The results for a panel of 152 developing countries over the period 1977-2002 support a negative linear relationship between external debt and economic growth, and between debt service and investment. These effects are found to be stronger in the Low-Income Countries than in the overall sample, raising concern about the dramatic effect that debt has on economic performance in the world's poorest countries. In LICs, a debt reduction from a debt-to-exports ratio of 300 to the HIPC threshold of 150 is estimated to add more than one percentage point to per capita GDP growth, and a debt service reduction is found to be more than two times more effective than an equal increase in foreign aid. Eventually, external debt impairs economic growth through the liquidity constraint, the creation of macroeconomic instability, the lower efficiency of investment, and its effect on macroeconomic policies and institutional development.
\end{abstract}

Keywords: External Debt, HIPC, Debt Relief, Economic Growth

JEL Classification: C33, F34, H63, O11

\footnotetext{
${ }^{1}$ Università Politecnica delle Marche - Dipartimento di Economia, Piazza Martelli 8, 60121 Ancona - Italy. Email: presbitero@dea.unian.it. The author thanks M. Arnone, L. Bandiera, A. Kraay, L. Papi, S. Lala, M. Mazzoli, R. Lucchetti and A. Lo Turco for the useful suggestions. He also thanks all the participants to Workshop on "Economic Policy and Open Economy Macro" (Milan, May $21^{\text {st }}-22^{\text {nd }} 2005$ ) for comments on an earlier draft of this paper. The usual disclaimers apply.

This work will be presented at the " $46^{\circ}$ Riunione Scientifica Annuale" of the Società Italiana degli Economisti (SIE), Naples, October $21^{\text {st }}-22^{\text {nd. }}$
} 


\section{Introduction}

The HIPC Initiative, launched jointly by the World Bank and the International Monetary Fund in 1996, has highlighted the great relevance that high external debts has for economic performance. The presence of a large indebtedness has different effects on poor countries, not only related to their macroeconomic performance, but also to political and institutional aspects. High debts could undermine the effectiveness of structural reforms aimed to enhance growth and poverty reduction. The permanent fiscal crisis and the heavy administrative burden - due to the number of rescheduling and different creditors (at least 31, in HIPCs) and to the large number of currencies (at least 26) in which debt is denominated - can undermine the development of sound institutions, capable of making strategic choices [Moss and Chiang, 2003].

However, this paper focuses exclusively on the economic consequences of high debts in poor countries, with the goal of re-examining the channels through which external debt impinges on investment and on economic growth. In fact, even if the theoretical literature on this topic is well established and it is basically based on the debt overhang hypothesis and on the liquidity constraints due to debt service payments, the empirical evidence is mixed and lacks of a general agreement on the real effects of debt on economic performance.

Having a clearer idea of which are the channels through which the debt-investment and the debt-growth relations work is important in order to design better policies in Highly Indebted Poor Countries (HIPC), giving different weights and priorities to stock or flows reductions. The Initiative, in fact, is designed to reduce the external indebtedness up to a certain threshold, fixed at a Net Present Value of external debt-to-GDP ratio of 150, which is considered sustainable. However, there are no theoretical reasons behind the choice of this particular threshold, which is based on historical values and on the general presumption that the debt growth relationship in described by a bell curve ${ }^{2}$.

The aim of this paper is to investigate the debt-growth nexus, looking directly both at the debt-growth, and at the debt-investment relationships, in order to find empirical evidence the so-called "disincentive effects" of high debts, due to the debt overhang and to macroeconomic instability, as well as the "liquidity constraint", which refers to the adverse effect that debt service has on investment and growth.

Therefore, we will look at a dynamic growth equation and at an investment model, which are estimated taking the System-GMM estimator as a benchmark, and checking the robustness of the main results using different estimators (Differenced-GMM, LSDV, OLS).

The main contribution of this work is that we find a linear and negative relationship between external debt and growth in poor countries. Contrary to recent empirical studies [Pattillo et al., 2002 and Clements et al., 2004], we do not find any evidence of an inverse U-shaped curve representing the debt-growth relation (the so-called Debt-Laffer curve). Indebtedness is generally found to reduce significantly income growth, with a semi-elasticity of debt-toexports ratio estimated to be approximately 1.2-1.4. The magnitude of the debt effect on GDP growth is estimated to be much larger in the LICs and in the HIPCs, than in the overall sample, suggesting that debt is a critical issue in the world's poorest countries, which do not have the capacity to deal with large indebtedness. A debt forgiveness in LICs, that reduces the NPV of debt-to-exports ratio from 300 to the HIPC Initiative threshold of 150, is estimated to raise per capita GDP growth by 1.15 percentage point.

\footnotetext{
${ }^{2}$ For a review of the main criticism related to the design and the implementation of the HIPC Initiative, see Arnone e Presbitero. [2005] and Birdsall and Deese [2002].
} 
Furthermore, the main channel through which external debt is found to affect economic growth seems to be to a reduction in the quality and efficiency of investment, rather than its level.

In order to check the validity of this finding, we investigate the debt investment relationship, starting with the estimation of a basic static model, as done in the literature [Clements et al., $2004]$ and, then, looking at a dynamic specification. The dynamic model does not confirm the negative relation between external indebtedness and investment, suggesting that large debt stocks do not actually lower the investment rate, but instead they could affect the economic performance because of a reduction in the quality and efficiency of investment and because of the macroeconomic instability that they generate. What really seems to affect the investment rate are debt flows, even if they do not have a direct effect on GDP growth: an increase in debt service payments crowds out investment by a factor of 0.2 . The liquidity constraint is generally much more severe in Low-Income countries, and, in those countries, a reduction of debt service is found to be more than twice effective than an equal amount of foreign aid, suggesting that the fungibility of aid is a critical issue in the poorest countries.

Eventually, our data imply that external indebtedness is a dramatic issue, particularly in the world's poorest countries. Debt service payments are a harsh constraint to investment, while the presence of a large external debt is likely to reduce the pace of economic growth. In fact, it generates an instable macroeconomic environment, which leads to short-termism and to less efficient investment, and it is also likely to delay economic reform and to obstruct sound macroeconomic policies, which are a critical determinant of economic growth.

It is worth noting that this preliminary conclusions need to be confirmed by further research on this topic. The analysis should focus on the Net Present Value of external debt and it has to include the institutional aspect, since policies are likely to affect both the debt management and the rate of economic growth. Furthermore, it is necessary to address the direction of causality between debt and growth and try to disentangle the crowding out of both public and total investment.

The remainder of the paper is as follows: the first section briefly reviews the theoretical and empirical literature on the debt growth nexus, section 3 presents the dataset, section 4 discusses some methodological and econometric issues, while section 5 and 6 discuss the empirical findings of the growth and investment models, and section 7 concludes and illustrates the future development of this field of research.

Annex A presents all the regression Tables.

\section{Theoretical and Empirical Literature}

High debts, particularly in LICs, have an adverse effect on the rate of investment and on economic growth, according to empirical evidence. There are disincentive effects, due to debt overhang and uncertainty, cash flow effects, since debt service repayments crowd out public investment, and moral hazard effects [Claessens et al., 1996].

\subsection{Debt Overhang}

One of the main channels through which high debts impair economic performance is the "Debt Overhang" effect [Krugman, 1988 and Sachs, 1989]: a large debt burden squeezes investments, because the returns are "taxed away" by the foreign creditors. Debt overhang could disincentive investments in human capital and new technologies, and the government's 
willingness to adopt structural reforms and fiscal adjustments, leading to a poverty trap [Sachs, 2002].

The relationship between debt and growth is generally represented by an inverse U-shaped curve, even if some early studies [Cline, 1995 and Cohen, 1993] reject the hypothesis that the debt burden reduces investment.

The most recent evidence finds different levels of debt ratios ${ }^{3}$ at which the impact of external debt on growth becomes negative, because of different sample of countries. Pattillo et al. [2002] find that the critical value, for 93 developing countries, is roughly 160-170; Clements et al. [2003] look at 55 LICs and estimate a ratio of debt to exports of approximately 115-120; while in Elbadawi et al. [1997] the maximum of the inverse-U shaped curve in 99 developing countries corresponds to a ratio of the current stock of debt to GDP equal to 97. Pattillo et al. [2002] and Clements et al. [2003] estimate that debt relief, as designed by the HIPC Initiative, could contribute to roughly a one percentage point increase in output growth. In two very recent papers, Cordella et al. [2005] and Imbs and Ranciere [2005] find evidence of non linearities in the debt growth relation: the former move from the previous literature arguing that the relation is a bell shaped curve but, over a certain threshold, the debt effect on growth is nil; the latter use a non parametric technique to support the Debt-Laffer curve, arguing that better institutions reduce the magnitude of the debt overhang.

\section{2 "Crowding Out" effect}

Also debt flows affect economic performance: a reduction in current debt service increases the current level of investments, for any given level of future indebtedness. Since the HIPCs receive net positive resource transfers, the disincentive effect of a large debt burden might be mitigated and the debt service payments could be a critical constraint to economic growth.

Some authors [Pattillo et al. 2002, 2004] does not find evidence of a significant "crowding out" effect, while others (i.e. Chowdhury [2004], Clements et al. [2003], Elbadawi et al., [1997]) find that both debt burden and debt service obligations squeeze investment and economic performance. Cohen [1993] rejects empirically the "debt overhang" hypothesis and supports the "crowding out" effect, whose magnitude is 0.35. Hansen [2004] estimates that debt service has a negative impact on investment (the point estimate is 0.33 ) and growth, while Presbitero [2005] find empirical evidence supporting the crowding out effect of investment due to the burden of debt service payments on the budget constraint (the point estimate ranges from 0.27 to 0.15 ). Clements et al. [2003] calculate that a reduction in debt service from $8.7 \%$ of GDP to $3 \%$ will increase public investment by $0.7-0.8 \%$, and this augmented investment will be translated in a per capita GDP growth increase of $0.1-0.2 \%$.

\subsection{Uncertainty}

The stock of debt has another effect on economic performance, due to uncertainty associated with the level of external debt (i.e. high and volatile inflation, interest rates). Risk of default, rescheduling and arrears are likely to increase the volatility of future inflows and additional lending, while the access to capital markets depends on the perceived sustainability [Gunning

\footnotetext{
${ }^{3}$ The main measures of external indebtedness are the ratios of external debt over GDP and over exports. The second ratio, in particular, has the advantage of being more informative on the capacity of a country to generate enough foreign currency to meet its debt obligations. On the other hand, however, it is more subject to the extreme volatility of exports in Low Income Countries. In order to take into account of the degree of concessionality embedded in the multilateral loans, the use of a measure of Net Present Value of debt is generally believed to better describe the real debt burden (the shortcomings, in this case, are related to the choice of the discount rate, see Arnone et al. [2005]).
} 
and Mash, 1998]. The outcome is a situation in which domestic and foreign investors are likely to exercise the "waiting" option [Serven, 1996]. Moreover, an unstable macroeconomic environment is likely to generate a misallocation of resources, maybe due to short-termism [Moss and Chiang, 2003], which reduces the efficiency and productivity of capital, leading to a slowdown of economic growth.

Pattillo et al. [2002] argue that the main channel through which debt affects economic growth is the quality and efficiency of investment instead of its level, because the exclusion of the investment rate from their growth regression does not change significantly the adverse debt effect.

Eventually, the evidence of a direct link between debt and growth remains unclear, since econometric results lack of robustness [Moss and Chiang, 2003]. In particular, empirical works should focus on a more accurate investigations of the real effects of indebtedness on economic performance in the HIPCs (or LICs), instead of dealing with all LDCs, since high debts are likely to affect economic growth through different channels, according to the specific macroeconomic environment. Furthermore, in order to draw a more realistic estimate of the impact of debt dynamics on economic performance, there should be a careful analysis of the debt effects on investment (and not only on economic growth), and also of the relevance of a policy or institutional variable, which is often neglected in this sort of studies.

\section{Sample and Data.}

To highlight the effect that the external stock of debt has on the economic growth and investment rates, this paper uses data for a panel of 152 developing countries, over the period 1977-2002.

Macroeconomic data are taken from the 2004 World Development Indicators (WDI) and from 2005 Global Development Finance. The educational variable, the gross primary enrolment rate, is integrated with the Barro-Lee dataset ${ }^{4}$. Data on the Net Present Value of external debt are from the World Bank and they cover 52 Low-Income countries over the period 1980$2002^{5}$. The use of the NPV of debt has the advantage of taking into account the degree of concessionality embedded in multilateral and bilateral loans made to developing countries. Therefore, it is a better indicator of debt burden, since it considers the real stock of debt that impinges on the budget constraint. Descriptive statistics of the main variables are reported in Table A, while the pairwise correlations are in Table B (in Annex A).

Among the 152 developing countries, it is possible to identify different sub samples, according to the WB classifications (64 Low Income Countries, 48 Severely Indebted Countries, and 38 High Indebted Poor Countries] and to previous studies (Pattillo et al. [2002], related to 92 developing countries) and Clements et al. [2004], 55 LICs).

The institutional variables are from the IRIS-3 dataset, constructed by Stephen Knack and the IRIS Center, University of Maryland, from monthly ICRG data provided by the PRS Group. The institutional indicators cover only the period 1984-1997, so that their inclusion into the analysis reduces the sample size, dropping 9 years. In particular, Rule of Law and the Quality of Bureaucracy range in value from $0-6$, with high values indicating respectively sound political institutions and strength and expertise to govern; and Risk of Expropriation of Private Investment ranges in value from $0-10$, with high values indicating a low probability of outright confiscation and forced nationalization.

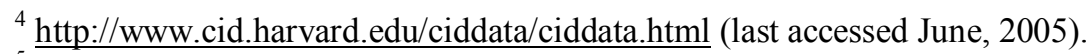

5 The author thanks M. Arnone and L. Bandiera for the provision of the data on NPV of debt.
} 
In order to wash out at least part of the business cycle effects, we check the robustness of our main findings using three-year averages, according to the literature [Clements et al. 2003]: this procedure has the drawback of reducing the time horizon to eight periods. For that reason, we do not use five-year averages, which would reduce the time dimension even further.

\section{Model and Econometrics}

The empirical literature about the estimation of growth models started with the cross-country growth regressions à la Barro, which allows for testing conditional convergence and the augmented Solow model [Mankiw, Romer and Weil, 1992]. However, this sort of empirical research is flawed by different shortcomings, since the explanatory variables are generally endogenous, and also because there are many country specific effects that cannot be identified, leading to the omitted variable bias ${ }^{6}$.

The availability of panel datasets allows for the overcoming of these problems, since the basic within group estimator is able to wash out the country specific effect and makes the conditional convergence estimate no more biased by the omitted initial level of efficiency. Furthermore, the availability of yearly data provides more instruments in order to solve the endogeneity problem.

\subsection{The Growth model}

The growth equation that has to be estimated is:

$$
\Delta y_{i t}=\alpha+(\beta-1) y_{i t-1}+\sum_{j=1}^{k} \delta_{j} x_{i t j}+\sum_{h=1}^{2} \gamma_{h} d e b t_{i t h}+n_{i}+\varepsilon_{i t}
$$

Which is equivalent to:

$$
y_{i t}=\alpha+\beta y_{i t-1}+\sum_{j=1}^{k} \delta_{j} x_{i t j}+\sum_{h=1}^{2} \gamma_{h} d e b t_{i t h}+n_{i}+\varepsilon_{i t}
$$

where $y_{i t}$ is the logarithm of per capita GDP of country $i$ at time $t$ (and $\Delta y$ is the GDP growth rate calculated as log difference), $\mathrm{y}_{\mathrm{it}-1}$ is the log of lagged income, that should capture the conditional convergence of income across countries, $x_{i t j}$ is a set of control variables (including macroeconomic, institutional and social variables), debt ${ }_{\text {ith }}$ are different indicators of the external debt burden, $n_{i}$ captures the effects of the country $i$ that are time invariant, and the classical error term $\varepsilon_{\mathrm{it}}$ is referred to the variability across time and countries.

The variables of interest are related to the stock of debt and to the debt service and the theoretical hypothesis that are tested are:

- the "crowding out" effect, which predicts a lower growth due to lower investment, since the debt service payments soak up resources from budget balance, and

- the "debt overhang" effect, that highlights the adverse effect that the stock of debt has on the rate of investment and, as a consequence, on the rate of economic growth.

\footnotetext{
${ }^{6}$ We present the methodological issues referring to the growth model, since they can be easily extended at the investment equation, discussed in section 6 .
} 


\subsection{The Choice of the Estimator}

The baseline analysis of the paper is done using the LSDV estimator, for taking into account the individual country specific effects. Even if this estimator is flawed by the dynamic structure of the growth model and by the endogeneity of the variables included into the regression, large part of the literature keeps on using the LSDV estimator, at least as a benchmark (see, i.e. Clements et al. [2003], Pattillo et al. [2002, 2004] and Gupta et al. [2005]).

The dynamic structure of the model makes the OLS estimator upwards biased and inconsistent, since the lagged level of income is correlated with the error term. However, even the within transformation does not solve the problem: the LSDV estimator transforms the model (2) subtracting out the time series means of each variable for each country and than estimate the new model using OLS:

$$
y_{i t}-\bar{y}_{i .}=\beta\left(y_{i t-1}-\bar{y}_{i .-1}\right)+\sum_{j=1}^{k} \delta_{j}\left(x_{i t j}-\bar{x}_{i . j}\right)+\sum_{h=1}^{2} \gamma_{h}\left(d e b t_{i t h}-\overline{d e b t_{i . h}}\right)+\left(\varepsilon_{i t}-\bar{\varepsilon}_{i .}\right)
$$

This procedure has the advantage of wiping out the country specific effects $n_{i}$ that are invariant over time, but the coefficients are likely to be biased downwards and Nickell [1981] has showed that for a finite $\mathrm{T}$ the within group estimator is biased and inconsistent, since the first regressor (lagged income) is still correlated with the new error term [Baltagi, 1995].

Among the possible solutions, Anderson and Hsiao [1981] propose the first difference transformation of the model and the use of the past level of income in t-2 as instrument for the first difference $\Delta y_{i t-1}$. This instrumental variable technique leads to consistent but not necessarily efficient estimates, because it does not use all the available moment conditions [Baltagi, 1995].

Therefore, the growth equation can be estimated using the Generalized Method of Moments (GMM) technique, using both the Differenced-GMM estimator [Arellano and Bond, 1991] and the System-GMM [Blundell and Bond, 1998].

The Arellano and Bond estimator (Differenced-GMM, thereafter also AB) starts from the first differenced equation (4), which gets rid of the time invariant effects, and extends the Anderson and Hsiao idea considering also the past values lagged more than two periods as valid instruments:

(4) $y_{i t}-y_{i t-1}=\beta\left(y_{i t-1}-y_{i t-2}\right)+\sum_{j=1}^{k} \delta_{j}\left(x_{i t j}-x_{i t-1 j}\right)+\sum_{h=1}^{2} \gamma_{h}\left(d e b t_{i t h}-d e b t_{i t-1 h}\right)+\left(\varepsilon_{i t}-\varepsilon_{i t-1}\right)$

The $\mathrm{AB}$ estimator uses all the feasible lagged values of the predetermined variables $\left(\mathrm{x}_{\mathrm{j}}\right.$ and debt $_{\mathrm{h}}$ ) as valid instruments for equation (4), and it obtains more efficient and consistent (asymptotically) estimates than the Anderson-Hsiao IV estimator (AH).

Blundell and Bond [1998] show that when $\beta$ approaches to one, so that the dependent variable follows a path close to a random walk, the differenced-GMM has poor finite sample properties, and it is downwards biased, especially when $\mathrm{T}$ is small. This is due to a weak instrument problem, since the lagged level of income is weakly correlated with the first differences: in terms of equation (4), the $\log$ of GDP in t-3, t-4 and so forth are poor instrument for $\Delta \mathrm{y}_{\mathrm{it}-1}$. Bond et al. [2001] argue that this is likely to be a serious issue for autoregressive model, like the growth equation (2), when the per capita GDP is observed in 3 or 5 years averages and $\mathrm{T}$ is necessarily small (no more than 10 periods). 
Therefore, Blundell and Bond [1997] propose another estimator - the System-GMM (thereafter also BB) - derived from the estimation of a system of two simultaneous equations, one in levels (with lagged first differences as instruments) and the other in first differences (with lagged levels as instruments). The $\mathrm{BB}$ estimator is shown to perform better than the $\mathrm{AB}$ one when series are persistent ( $\beta$ close to unity) and there is a dramatic reduction in the finite sample bias due to the exploitation of additional moment conditions. Blundell et al. [2002] confirm that this results hold also for multivariate dynamic panel models: Monte Carlo simulations show that the first differenced GMM is characterised by a large bias and low precision when series are persistent, while the system-GMM both improves the precision and reduces the finite sample bias.

Among the GMM estimators, another choice is between the one-step and the two-step estimator, which are asymptotically equivalent if $\varepsilon \sim \operatorname{IID}\left(0, \sigma^{2}\right)$ [Blundell and Bond, 1997]. The one-step GMM estimator, built under the strong assumption that the weighting matrix is known, is efficient under the restrictive assumptions of homescedasticity and not correlation of the error terms. On the other hand, in the presence of heteroscedasticity and serial correlation, efficient GMM estimation requires the two-step GMM, which uses a consistent estimate of the weighting matrix, using the residuals from the one-step estimate [Davidson and MacKinnon, 2004]. Though asymptotically more efficient, the two-step GMM presents estimates of the standard errors that tend to be severely downward biased. However, it is possible to solve this problem using the finite-sample correction to the two-step covariance matrix derived by Windmeijer, which can make two-step robust GMM estimates more efficient than one-step robust ones, especially for system GMM [Roodman, 2003]

One of the main problems of using the GMM estimators is that their properties are valid asymptotically, because they are generally developed for micro data, in which the spatial dimension is very large.

A possible solution in dealing with dynamic panel data models and small samples was proposed by Kiviet [1995], who develops an approximation of the small sample bias for the LSDV estimator in balanced panel where $\mathrm{N}$ is small. In this way, he constructs a corrected within group estimator, that is shown to be more attractive and efficient than the $\mathrm{AB}$ and $\mathrm{AH}$ estimators, for small $\mathrm{T}$ and $\mathrm{N}$ [Adam, 1998]. Bruno [2005] overcomes the main shortcoming of the Kiviet's estimator, analysing the performance of the LSDV bias in unbalanced panels. Monte Carlo simulations show that the bias of the autoregressive parameter is decreasing in the time dimension and in the degree of unbalancedness. Bruno derives approximations of various order to the bias of the LSDV estimator in dynamic unbalanced panel and constructs a corrected LSDV estimator (LSDVC, or KIVIET, thereafter) which removes one of the main causes for the limited applicability of the within group estimator ${ }^{7}$. However, the second major weakness of this technique, the strictly exogeneity of the other regressors, remains unsolved and undermines the applicability of this estimators to dynamic growth models.

Dealing with macroeconomic and cross country data makes the small sample a critical issue, and it becomes very difficult to disentangle which kind of estimator is preferable.

Judson and Owen [1999], using Monte Carlo simulations with small $\mathrm{N}$ and $\mathrm{T}$, confirm the upward bias of the OLS and the downward bias of the LSDV, and they make a comparison between these estimators and KIVIET, $\mathrm{AH}$ and AB. They argue in favour of the Kiviet's corrected LSDV estimator in balanced panel, while in unbalanced panel, the within group is

\footnotetext{
${ }^{7}$ For the practical routine for Stata8, which allows for the corrected estimates, depending on the original estimator (Anderson and Hsiao, Arellano and Bond, Blundell and Bond), see Bruno [2005].
} 
preferable when $\mathrm{T}$ is close to 30 , while when $\mathrm{T}$ becomes smaller $(<10)$ the differenced-GMM is the best alternative. Furthermore, they state that the one-step GMM outperforms the twostep one, and that a restricted version (with few instead of all feasible lagged values of the exogenous regressors as instruments) does not reduce the performance of the $\mathrm{AB}$ estimator.

Bond et al. [2001] provide a useful insight in the GMM estimation of dynamic growth models: they ague that the pooled OLS and the LSDV estimators should be considered respectively as the upper and lower bound, because of the individual specific effect (which biases upwards the OLS) and of the Nickel bias of the fixed effect model. As a result, a consistent estimate should lie between the OLS and LSDV ones and, whether the differenced GMM coefficient is close to or lower than the within group one, this is likely a sign that the $\mathrm{AB}$ estimates are biased downward (maybe because of a weak instrument problem). Thus, if this is the case, the use of system-GMM is highly recommended, and its estimates should lie between OLS and LSDV. This conclusion is supported by the empirical testing of the augmented Solow model, in which Hoeffler [2002] finds evidence of the downward bias of the $\mathrm{AB}$ estimator and states that the system-GMM is both valid and highly informative ${ }^{8}$.

With these insights, it seems clear that there is not a method which can be considered as the best solution. Therefore, the strategy of the empirical part is aimed to see if the expected debt effects are significant across different specifications and to find out the more consistent point estimate. Because of the lack of a dominant estimator, we look at different estimates, in order to find confirm of the fact that the differenced-GMM is likely to be biased downwards, because of the persistency of the series. For the system-GMM to be taken as a benchmark, there are three conditions that must be satisfied:

- the system-GMM lies between the upper and lower bound represented by OLS and LSDV,

- there is a gain in efficiency, and

- the instrument set is valid.

Whether this is the case, we look at the two-step system-GMM results, which econometric literature argues are more precise even for growth regressions [Bond et al., 2001, Nkurunzita and Bates, 2003, Hoeffler, 2002].

\section{The Growth Model: Results}

\subsection{Choice of the Estimator}

The first part of the empirical analysis concerns the estimation of the growth equation (1) using all the different estimators, in order to see whether the theoretical arguments against the Differenced-GMM and in support of the System-GMM are confirmed by the data.

The basic growth model includes the log of lagged income, two debt variables (total debt service as a share of GDP and the external debt-to-exports ratio) and, as additional controls, according to the empirical growth literature (see, among others, Easterly et al. [1997], Clements et al. [2004], Pattillo et al. [2002, 2004]), the population growth rate, a measure of openness, the investment rate, the budget balance, terms of trade, the primary school

\footnotetext{
${ }^{8}$ Hoeffler uses the one-step GMM, because of the standard errors bias of the estimator, which, instead, we address using the Windmeijer correction. Following Hoeffler, Nkurunziza and Bates [2002], take the systemGMM as their benchmark, for a panel growth regression in Africa.
} 
enrolment rate (as a measure of human capital), inflation and M2 as financial sector indicators.

The results for 3-year average data, reported in Table 1, are consistent with the theoretical arguments against the differenced-GMM and supporting the BB estimator ${ }^{9}$. Considering the autoregressive parameter $\beta$, the estimates (which refers to $\beta-1$ ) show that the degree of persistence of GDP per capita is very high ( $\beta$ ranges between 0.94 and 0.99 ) and, because the series is similar to a random walk, the differenced-GMM is likely to be downward biased because of weak instruments. In fact, the $A B$ values for $\beta-1$ are close or even below the LSDV lower bound, while the BB coefficients are higher and more similar to the upper bound represented by pooled-OLS.

With respect to the other variable of interest - the stock of external debt - the system GMM estimates lies again between the LSDV and the OLS values, while the differenced-GMM is even more biased than the within group estimator, reporting a coefficient of -1.86 , while the corresponding figure for the (two-step) system-GMM is -1.2.

The use of yearly data (Table 2) allows for a larger sample, even if data are flawed by business cycle dynamics. However, the estimates confirm the basic findings about the behavior of the four estimators. The degree of persistence is slightly lower, while the range between OLS and LSDV is 2.4 times larger, meaning that the downward bias of LSDV and differenced-GMM is more severe using yearly data than averages ( $\beta$ is 0.85 instead of 0.98 , as reported by system-GMM). Contrary to the previous results, now the one-step GMM seem to be more efficient, especially for the BB estimator, where the standard errors make quite all the regressors not significant. With respect to the debt stock variable, the downward bias is exacerbated and the $\mathrm{AB}$ coefficients are much lower than the LSDV ones. Therefore, the results of the system-GMM seem more reliable, and the estimated coefficient is -1.3, similar to what obtained using average data.

Another possible estimation technique, generally followed by the empirical literature (among others, Bond et al. [2004]), implies the use of a smaller set of instruments [Judson and Owen, 1999], limited to 2, 3 or 5 lags, instead of all feasible lags. Tables 3 and 4 report the results obtained for the one-step and two-step System-GMM, both using average and yearly data. With respect to three-year average data, the comparison highlights that there are no striking differences: the point estimate on the autoregressive parameter becomes closer to the OLS, suggesting a possible upward bias, while the debt semi-elasticity is quite stable across different specifications. Looking at yearly data (Tables 2 and 4), the one-step estimator seems to converge to more reliable point estimates (lower than OLS) thanks to the smaller instrument set. For the two-step estimator there is also a dramatic increase in efficiency, since the coefficients of interest turn out to be significant and their estimates are close to the onestep ones, and lower than OLS.

The values of the Hansen $\mathrm{J}$ statistic test ${ }^{10}$ for over-identifying restrictions confirm that the instrument set can be considered valid, while tests for serial correlation point out, as expected,

\footnotetext{
${ }^{9}$ All the estimates consider the "robust estimator of the covariance matrix of the parameter estimates be calculated. The resulting standard error estimates are consistent in the presence of any pattern of heteroskedasticity and autocorrelation within panels. In two-step estimation, the standard covariance matrix is already robust in theory--but typically yields standard errors that are downward biased [but they are corrected using...] the finite-sample correction for the two-step covariance matrix developed by Windmeijer" [Roodman, 2005].

10 In Stata 8, the command "xtabond2 reports a test of over-identifying restrictions - whether the instruments, as a group, appear exogenous. For one-step non-robust estimation, it reports the Sargan statistic, which is the minimized value of the one-step GMM criterion function. But the Sargan statistic is not robust to heteroscedasticity or autocorrelation. So for one-step robust estimation (and for all two-step estimation),
} 
that we reject the null of not autocorrelation of the first order, but we cannot reject the hypothesis of no autocorrelation of the second order. Moreover, the difference Sargan test, which compares the differenced-GMM and the System-GMM results, confirms the validity of the System-GMM: we cannot reject the null hypothesis of the validity of the level moment conditions [Blundell et al., 2000]. Therefore, we can be confident that System-GMM is a good estimator for the growth model, at least better than the differenced-GMM, which is severely downward biased.

\subsection{Alternative Specifications of the Model}

Given the previous findings, we could be confident about the efficiency and precision of the System-GMM estimator, at least in comparison with differenced-GMM and the basic within group. Therefore, the focus will be on the results obtained using the BB estimator ${ }^{11}$, even if the validity of results is checked using different estimators (AB, OLS and LSDV) and different specifications [Bond et al., 2001, Hoeffler, 2002].

Looking at the previous estimates at some other preliminary findings [Presbitero, 2005], it is possible to estimate a more parsimonious model dropping the measure of openness, the M2 indicator, which are generally not significant. Furthermore, since the aim of the paper is the evaluation of the debt-growth nexus, we keep on controlling for the debt service ratio and we will check the possibility of a quadratic relationship between external debt and growth, as suggested by Clements et al. [2004] and Pattillo et al. [2002, 2004].

Eventually, we use different debt indicators (total debt service-to-export ratio, and external debt-to-GDP ratio), in order to test the robustness of our findings, and we estimate the growth equation without the investment ratio variable. This is done because the inclusion of investment is likely to bias the results, since part of the negative effects that debt has on economic performance should already be embedded in a lower investment ratio. Thus, without investment, we expect the debt semi-elasticity to be higher, since it should include the debt overhang effect on investment together with the general negative effect on economic growth.

\subsubsection{Different Debt Indicators}

Table 5 reports the results obtained with different debt indicators, using the parsimonious specification and the System-GMM estimator: debt stock indicators are always significant at $5 \%$ level of confidence, while the debt service variables are not significant across all specifications $^{12}$. Therefore, it does not seem that there is any evidence that debt service repayment have an adverse effect on the rate of economic growth. The main channel through which debt impinges directly on economic performance appears to be the presence of a high level of indebtedness. The point estimate of this negative effect ranges between 0.73 to 1.13 for the debt-to-exports ratio, and from 1.02 to 1.50 for the debt-to-GDP ratio, according to different specifications. This means that, on average (column 3), a 10\% increase in the debtto-export ratio reduces the rate of per capita GDP growth by 0.11 ., while a reduction of the ratio from its average level to the HIPC threshold of 150 will boost economic growth by 0.30 , and halving the ratio from $300 \%$ to $150 \%$ will add half point to GDP growth.

\footnotetext{
xtabond2 reports the Hansen J statistic, which is the minimized value of the two-step GMM criterion function, and is robust" [Roodman, 2003].

${ }^{11}$ Controlling both the one-step and two-step estimators, and with the complete and restricted (3 lags) set on instruments. The regression outputs for the other estimators are not showed for the sake of brevity, but they are available on request from the author.

${ }^{12}$ This is still valid using the one-step estimator, even if in some regressions the debt service ratio becomes significant at $10 \%$.
} 


\subsubsection{Quadratic Specification}

The empirical evidence does not confirm the hypothesis of a non-linear relationship between debt and growth, as stated in Pattillo et al. [2002] and Clements et al. [2004]. In fact, just one out of eight specifications in Table 6 is consistent with a quadratic model, while the other regressions are misspecified. However, there is not an inverse U-shaped curve, but just a negative relation between debt and growth: the point estimate confirms that the minimum of the curve is for a very high level of the debt ratio, higher than the 95th percentile of the sample, meaning that the basic relationship is negative and follows a downward sloping Ushaped curve. ${ }^{13}$ This basic negative link between debt and growth (and the lack of an inverse U-shaped curve) could be explained by the sample of countries: we are dealing with poor countries, in which debt is likely to impair economic growth. The left side of the curve, in which the effect of debt is positive, should be occupied by industrialized and low indebted countries, in which more debt leads to more growth.

\subsubsection{Exclusion of investment}

The last part of the empirical estimation of the debt-growth nexus implies the exclusion of the investment variable from the model, to control for the possibility that part of the debt effect is embedded in a lower investment ratio, biasing the estimates. In fact, if the debt effect is much larger when investment is excluded, this means that high debts reduce the investment rate, as well as its efficiency, while, if the difference is not really strong, this means that the main channel through which debt affects economic growth is the quality and efficiency of investment.

Table B presents the differences in debt stock indicators when investment is included or not in the regression: the coefficients are not significantly different, and only for the complete specification (Model 1) there is a sizable difference in the point estimate of the debt-to-export ratio, even if, as expected, the exclusion of investment rate increase slightly the semielasticity of debt ratios. Furthermore, the quadratic specification does not fit the data even excluding investment, and the debt service ratio remains not significant, suggesting that its adverse effect works through the crowding out of investment, and that it does not affect directly the rate of GDP growth (see Table 7 for details). These findings support the hypothesis that high debts do not lower significantly the investment level, but they reduce the quality and the efficiency of investment: this misallocation of resources could be due to shorttermism, to lack of innovation, and it is consistent with the theoretical hypothesis of debt overhang, which states that return of investment will be taxed away to repay the debt, leading to short run projects.

Table B: Exclusion of Investment

\begin{tabular}{|c|c|c|c|c|}
\hline & \multicolumn{2}{|c|}{ Model 1} & \multicolumn{2}{|c|}{ Model 2} \\
\hline & Investment & No investment & Investment & No investment \\
\hline
\end{tabular}

\footnotetext{
13 This basic conclusion is confirmed also using different estimators and different specifications of the model (results not shown for reasons of space and available on request from the author). Furthermore, Presbitero [2005] confirm the idea of a basic linear (or quadratic) negative relationship between debt and growth, using the LSDV and $\mathrm{AB}$ estimators.
} 


\begin{tabular}{|l|c|c|c|c|}
\hline log of External & -0.691 & -1.180 & -1.393 & -1.213 \\
Debt/Exports & $(0.09)$ & $(0.00)$ & $(0.00)$ & $(0.01)$ \\
\hline log of External & -1.507 & -1.731 & -1.374 & -1.446 \\
Debt/GDP & $(0.00)$ & $(0.00)$ & $(0.00)$ & $(0.10)$ \\
\hline
\end{tabular}

Notes: P-values in brackets. All coefficients are significant at $10 \%$ level of confidence. Model 1 refers to the general growth model (see Table 1), while Model 2 is the parsimonious specification, without M2 and openness (see Table 5). All estimates refer to three lags System-GMM, 3-years average data.

\subsection{Debt Effects and Determinants of Economic Growth}

Until now, the empirical work supports the use of System-GMM, which perform quite similarly using the complete or the restricted instrument set, and a linear-log specification between economic growth and external debt, excluding the possibility of an inverse U-shaped curve, both using the debt-to-export and the debt-to-GDP ratios. Turning to the magnitude of the different growth determinants, the semi-elasticity of GDP growth to debt-to-export ratio is quite stable at 1.2-1.3, across different specifications. A sound fiscal stance have a positive and strong effect on growth, since a $1 \%$ reduction in budget deficit boosts income growth by roughly a fifth of percentage point. The coefficients on investment rate and population growth are consistent with the Solow model, since a $1 \%$ increase in the investment rate enhance GDP growth by approximately $0.2 \%$, while the negative population effect is generally stronger ( $1 \%$ more in population growth rate decrease GDP growth by around half percentage point). The proxy for human capital, the primary school enrolment rate, is not always significant, even if the sign is positive, as predicted by the augmented Solow model.

The behavior of terms of trade and openness is instead contrary to expectations, since they have a negative effect on economic performance, even if it generally turns not significant with yearly data, probably because of their volatility. Looking at the financial sector indicators, M2 is usually not significant, while high inflation hinders economic growth, supporting the reasons for stabilization plans and macroeconomic adjustment. Furthermore, high inflation, together with high debts, is a proxy for the degree of uncertainty and instability of the macroeconomic environment, which necessarily reduce investment and the pace of economic growth. Eventually, there is evidence of a conditional convergence between developing countries, since the level of lagged GDP has a significant and negative effect on income growth.

\subsection{Different Sub-samples}

Until now, empirical evidence confirms that high debts impair economic growth, particularly through a reduction in investment efficiency and quality. The magnitude of the debt constraint in all the developing countries included in the analysis, however, is not really strong, since a debt reduction consistent with the HIPC Initiative will boost per capita GDP growth by half of a percentage point.

None the less, this conclusion is referred to the average country of the sample, while it is reasonable to believe that large external debt could have a different impact, according to the level of income and indebtedness of a country. In particular, middle income countries, which are also generally better governed, could afford larger debts, while in the world's poorest countries, high debts could have more dramatic effect on income growth. This could be due to 
more severe budget constraint, to bad management and governance, and to poor institutional quality ${ }^{14}$.

To test this hypothesis, we estimate the growth equation (1) only for a particular subset of countries, namely the LICs and the HIPCs, in order to establish if the debt semi-elasticity is significantly larger than in the overall sample. The comparison is done referring to yearly data, because otherwise the sample size becomes too small (less than 140 observations) ${ }^{15}$.

The comparison between the overall sample, LICs and HIPCs, highlights that in the poorest countries external debt has a negative effect on income growth two times higher than in the overall sample (Table 8), both including or excluding investment: a 10\% increase in external indebtedness reduces the growth rate by a fifth of percentage point in LICs, instead than a tenth. Furthermore, in the highly indebted poor countries, the exclusion of the investment rate implies an increase in the magnitude of the debt effect, suggesting that, in those countries, high debts adversely affect not only the quality, but also the level of investment.

\subsection{Net Present Value of Debt}

One of the main drawbacks of this analysis is that it relies on the use of nominal values of debt, which do not take into account the degree of concessionality: using of the Net Present Value of debt overcomes this problem and provides more reliable estimates, since it measures the real debt burden. However, historical data on NPV of debt are not available for all the sample, but only for 52 Low-Income countries. The estimation of the growth model (Table 9), both using the complete and the parsimonious specification, confirms the basic findings about the positive impact of budget balance and investment rate on GDP growth, the conditional convergence hypothesis, and the negative relationship between debt and growth ${ }^{16}$.

The inclusion of the quadratic term makes the debt-growth relationship non linear (column 35-7), but it is a U-shaped curve. The point estimates, however, suggest that the basic relation is negative, since the minimum of the $U$ curve is for very high value of the NPV of external debt to export (or GDP) ratio. According to Pattillo et al. [2002] and Clements et al. [2004], who estimate an inverse U-shaped curve, the marginal effect becomes negative when the debt ratios are close to 60 or 80 : in our sample, the $5^{\text {th }}$ percentile of debt-to-exports ratio is 84 , so that the $95 \%$ of our observations should be in the negative-sloped side of the inverse Ushaped curve, justifying the reliability of our findings.

In terms of the impact of debt relief, these results show that a debt reduction from 300 to 150 of the NPV of debt-to-exports ratio contributes to more than 1 percentage point increase in the per capita GDP ratio (columns 1 and 2), which is an estimate slightly larger than in Pattillo et al. [2002] and in Clements et al. [2004].

\subsection{The Debt-Growth Nexus: Main Findings}

The empirical results confirm the basic conclusion of the Solow model, with a positive effect of investment and a negative effect of population dynamics an economic growth. Furthermore, the proxy for human capital has generally a positive impact, while inflation, which could be considered a proxy for the instability of the macroeconomic environment,

\footnotetext{
${ }^{14}$ On the relevance of institutions for the debt sustainability, see, among others, Kraay and Nehru [2004].

15 Since the estimation of sub samples reduces the sample size, we estimate the growth equation with the one step system-GMM. These results have to be taken with caution, since they are obtained using yearly data (which are affected by business cycle dynamics) and also because, in the LICs sub-sample, the first test of autocorrelation does not pass.

${ }^{16}$ The effect of population growth and human capital, instead, are not robust across different specifications.
} 
reduces the pace of economic growth. Eventually, a $1 \%$ reduction of fiscal deficit is showed to boost GDP growth by a fifth of percentage point.

Turning to the debt-growth nexus, the relationship between external debt and economic growth is linear and negative, and it does not find evidence of an inverse U-shaped curve. Debt service, instead, does not have a direct impact on GDP growth. These results are confirmed using different debt indicators, estimating different specifications of the growth equation, excluding investment from the regression, and considering different sub-samples. The semi-elasticity of GDP growth to the debt-to-exports ratio is quite stable at 1.2-1.4, meaning that a $10 \%$ increase in the debt ratio reduces the rate of per capita GDP growth by 0.12 percentage point. However, this debt effect is doubled in LICs, probably because in the word's poorest countries, poor institutional quality, weak policies and widespread corruption aggravate the adverse effect that indebtedness has on economic performance. The same level of debt, in fact, could be sustainable in a particular country, but it could be a dramatic burden for a country with worse governance.

Furthermore, high debts do not lower significantly the investment level, but they reduce the quality and the efficiency of investment: this misallocation of resources, maybe due to shorttermism, is consistent with "debt overhang", which states that return of investment will be taxed away to repay the debt, leading to short run projects.

A more reliable estimate of the real debt burden could be obtained using the Net Present Value of debt, which take into account the degree of concessionality embedded in multilateral and bilateral loans to poor countries: data for 52 LICs confirm that external debt has a strong negative impact on economic performance, since a debt reduction from a debt-to export ratio of 300 to the HIPC threshold of 150 is estimated to add more than a percentage point to per capita GDP growth rate.

\section{The Investment Model}

In order to perform an in-depth analysis of the debt-growth nexus, it is better to disentangle it in a two-step relationship, in which the first is the direct link between debt and investment, and the second is the usual growth equation we first study an investment model, as done, among others, by Cohen [1993] and Clements et al. [2004].

A first approach to the investment model $^{17}$ is the LSDV estimation of a static equation (5) in which the dependent variable is the investment ratio ${ }^{18}$, the $\mathrm{x}$ variables are a set of determinants of investment, and the variables of interest are the debt indicators:

$$
y_{i t}=\alpha+\sum_{j=1}^{k} \delta_{j} x_{i j}+\sum_{h=1}^{2} \gamma_{h} d e b t_{i t h}+n_{i}+\varepsilon_{i t}
$$

The previous static model is likely to be misspecified, since the current level of investment clearly depends on the level in the previous period and, furthermore, all the right-hand side variable are endogenous, leading to biased LSDV estimates. Thus, we specify a very simple

\footnotetext{
${ }^{17}$ This part of the analysis is based on an earlier version of the paper [Presbitero, 2005].

${ }^{18}$ There is no distinction between public and private investment (as in Cohen [1993] and Hansen [2004]), since the debt overhang effect should hinder both private and public investment, because of the "waiting option" and the level of uncertainty of the macroeconomic environment should discourage the private agents as well as the government. On the other hand, the crowding out effect is directly related to a reduction in public spending, but, given the complementarity of public and private investment, especially in LICs, a lack of investment in basic infrastructure is likely to crowds out private investment as well.
} 
dynamic model - equation (6) - in which the investment rate $y_{\text {it }}$ depends on its past value $y_{\text {it- } 1}$ and on the usual set of control and debt variables ( $\mathrm{x}_{\mathrm{itj}}$ and debt $\left.\mathrm{t}_{\mathrm{ith}}\right)$. In this way, it is also possible to disentangle the short run and the long run effects:

$$
y_{i t}=\alpha+\beta y_{i t-1}+\sum_{j=1}^{k} \delta_{j} x_{i t j}+\sum_{h=1}^{2} \gamma_{h} d e b t_{i t h}+n_{i}+\varepsilon_{i t}
$$

According to a large body of theoretical and empirical literature, we include in the analysis the degree of openness, an indicator of external shocks, the growth rate of GDP, which captures the accelerator effect [Agenor, 2005 ${ }^{19}$, the revenues rate, and human capital and institutional quality indicators. In addition, we include two financial indicators - the inflation rate and the share of domestic credit on GDP - and we control for the level of foreign aid, and different debt indicators, which test the "crowding out" and the "debt overhang" effects.

The rationale of this specification lies in the expected positive effect that the degree of openness, the level of GDP and schooling have on investment decisions. The effect of aid inflows is uncertain because of its fungibility: more aid not necessarily implies more investment [Easterly, 2001, 2002, Erixon, 2005]; moreover, there is evidence that aid effectiveness is related to institutional quality [Burnside and Dollar, 2000] and in countries with high corruption, aid is bounded to fail its targets. The inflation rate, the credit constraint and external shocks are expected to have a negative impact, even if inflation presents generally a small quantitative effect (see, e.g. Barro and Sala-i-Martin [2004], Agenor [2005] and Cohen [1993] $)^{20}$.

The first tables (10 and 11) present the results obtained using different estimators - LSDV, OLS, System-GMM, Differenced-GMM - which point out the bias of the AB estimates and support the use of the BB estimator as a benchmark. We compare model (6), using the quadratic specification for the debt-to-export ratio and both yearly and three-year average data: the same qualitative results are confirmed with different debt indicators.

Looking at the autoregressive parameter $\beta$, the estimates confirm, especially for the three-year average dataset, that the System-GMM lies between the upper bound of the OLS and the lower bound of the LSDV estimator. The difference-GMM, instead, is more downward biased than the LSDV. As a consequence, since the instrument set is tested to be valid and also the difference-Sargan test confirms the validity of the additional level moment conditions, the System-GMM estimator is taken as a benchmark. Furthermore, whether the sample size does not become too small, we take the results from the three-year average dataset as more reliable, because of the likely limited effect of business cycle dynamics on the estimates.

Looking at the last two columns of Table 10, all the coefficients except openness and the external debt ratios are significant with the expected signs. The autoregressive parameter is 0.63 , (while with yearly data it is 0.84 ), GDP growth, foreign aid, domestic credit, revenues and the level of schooling have a positive impact on investment. The positive coefficient on inflation could be explained by the so-called Tobin-Mundell effect, because higher expected inflation lowers the real interest rate, leading to a shift from money balances to physical investment [Agenor, 2005, p. 62]. However, the link between investment and inflation is

\footnotetext{
${ }^{19}$ A better specification of the investment model should consider also the variability of the real exchange rate and of inflation, which capture the macroeconomic instability better than the level of inflation. Further developments will include those variables in order to capture the importance of uncertainty on investment and economic growth.

${ }^{20}$ All the correlations between the independent variables and the growth rate of GDP and investment are in Annex A.
} 
generally ambiguous, since the level of inflation, and (foremost) its variability triggers macroeconomic instability and, thus, reduce investment.

With respect to the debt effect, there is evidence of the relevance of the liquidity constraint, while not of debt overhang, which is significant only across the LSDV and pooled-OLS estimates. The short run point estimate of the crowding out effect is $0.21-0.22$, while, in the long run, a $1 \%$ reduction in debt service will increase the investment rate by $0.57 \%$, which is a quantitative strong effect.

Since the quadratic specification is not significant, we estimate a linear-log relation, and we also look at different debt indicators. The results (see Table 14) confirm the negative effect of debt service payments on investment, while the debt stock indicator is generally not significant. The level of external indebtedness, therefore, does not have any explanatory power, once we control for the investment rate in the previous period, and we take into account revenues, aid, GDP growth, schooling, openness, credit and inflation. The magnitude of the crowding out effect ranges between 0.15 and 0.20 , so that a reduction of one percentage point in the debt service-to-GDP ratio adds a fifth of percentage point to the investment ratio. For a policy purpose, it is important to disentangle if the crowding out of investment due to debt serviced payments is larger in LICs than in all the developing countries of the sample. Table $\mathrm{C}$ actually shows that in LICs an increase in debt service has an adverse effect whose magnitude is more than two times higher than in the overall sample, both considering yearly and average data. Furthermore, the liquidity constraint seems to work only in LICs, because, in the non-LIC sample, the debt service ratio is not a significant explanatory variable. Eventually, the comparison between the overall sample and the LICs points out that the effectiveness of aid is quite small, so that in LICs only the $13 \%$ of foreign assistance is channelled in more investment, while this positive effect vanishes in the other developing countries. From a quantitative point of view, therefore, a good growth policy should prefer a reduction in debt service, as the last G8 meeting has done in June $2005^{21}$, instead of an increased foreign assistance, which is likely to be more fungible.

Table C: Crowding out of investment in LICs.

\begin{tabular}{|l|c|c|c|c|c|c|}
\hline & \multicolumn{3}{|c|}{ 3-years average data } & \multicolumn{3}{c|}{ Yearly data } \\
\hline & All sample & LIC & Non-LIC & All sample & LIC & Non-LIC \\
\hline TDS (\% of & $-0.21^{*}$ & $-0.44^{*}$ & -0.05 & $-0.08^{*}$ & $-0.20^{*}$ & -0.03 \\
GDP) & $(0.01)$ & $(0.02)$ & $(0.68)$ & $(0.00)$ & $(0.01)$ & $(0.74)$ \\
\hline Aid (\% of & $0.11^{*}$ & $0.13^{*}$ & 0.05 & 0.02 & 0.002 & -0.14 \\
GDP) & $(0.01)$ & $(0.04)$ & $(0.74)$ & $(0.32)$ & $(0.97)$ & $(0.37)$ \\
\hline Obs. & 375 & 148 & 227 & 766 & 287 & 479 \\
\hline
\end{tabular}

Notes: the reference is the model estimated in column 1 of Table I5 (two-step System-GMM). The statistical tests (OIR and autocorrelation tests) validate the specification in both the samples.

In order to confirm the presence of a financial constrain in the world's poorest countries, and the lack of relevance of the debt overhang, we estimate the debt-investment nexus using the NPV indicators of external debt, which provide a more reliable indication of the real debt burden. The estimates (Tables 13 and 14) support the previous findings, since external debt ratios are not significant, both using linear and quadratic specifications and yearly or average data. Debt service, instead, crowds out investment, and the point estimate are larger than in the overall sample: a one point increase in debt service means a reduction in the investment ratio ranging from 0.28 and 0.39 percentage points. The preferred specification (column 2 ,

\footnotetext{
${ }^{21}$ See, e.g., the Economist, print edition, June 16th, 2005
} 
Table 13) points out that the magnitude of the crowding out effect (0.39) is much larger than the effectiveness of foreign aid (0.15), implying that is desirable to forgive debt repayment instead of additional aid. The long run equilibrium, eventually, is consistent with a one-toone relationship between debt service and investment: a reduction of debt service of $1 \%$ of GDP raises the investment-to-GDP ratio by 1 percentage point. The significant and negative effect of the debt stock indicator is consistent with the idea that external debt squeeze investment, especially in HIPCs, but it is not robust across different specifications.

In sum, the dynamic model suggests that the relevant debt effect on investment works through the liquidity constraint channel. The stock of debt, coherently, with the findings of the growth model, is likely to affect the quality and the efficiency of investment, instead of its level. Eventually, comparing a 1\% increase in foreign aid and a $1 \%$ reduction in debt service, our estimates show that in LICs the fungibility of aid is a critical issue, so that reducing debt service payment has a much stringer effect, because it frees up resources in the government budget constraint that can be used for investment.

Looking at the NPV indicators, and considering Tables 9 and 13, a debt reduction from 300 to 150 of the NPV of debt-to-exports ratio raises the growth rate by 1 percentage point, and a $1 \%$ reduction in debt service, in steady state and other things equal, adds another $0.20-0.25 \%$ to the growth rate of GDP, while the short run impact is a $0.1 \%$ increase in the growth rate.

\section{Concluding Remarks}

This paper underlines the great relevance that high external debts have on economic performance in poor countries. Notwithstanding the different theoretical hypothesis on the possible effects that debt flows and stocks could have on investment and economic growth, the empirical evidence is mixed and has not reached a firm conclusion about the channels through which indebtedness impinges on economic growth in Low-Income countries. This is due mainly to the lack of robustness of econometric results, and this paper aims to fill part of the gap analysing how high debts affect economic growth rate and investment, making a distinction between the overall sample of developing countries, and a smaller sample of LICs. This is only part of the work that should be done in this research area. Further developments require a careful inclusion of: 1) the institutional aspect, 2) the direction of causality between debt and growth, 3) a more detailed investigation of debt effects in low income countries, 4) the effect of macroeconomic uncertainty on economic growth, including a measure of instability (e.g. volatility of exchange rate), and 5) the distinction between a total and public investment model.

Institutions and policies are likely to affect the debt-growth relationship, since a minimum level of institutional quality is required in order to reap the benefits of debt relief [Asiedu, 2003]. The specificity of a single country's economic and institutional environment is found to be relevant for a country's capability of managing debt and fostering growth [Kraay and Nehru, 2004]. Addressing the causality issue between debt and growth is necessary because it is not obvious that indebtedness is the source of low economic growth. Solving this problem could provide more relevant policy recommendations and it could be done using past values of the debt ratio and testing the Granger causality. Besides, from a policy perspective, it is also relevant to have a clear picture of the macroeconomic effects of large debts in Low Income countries exclusively. Eventually, the distinction between public and total investment in the investment model allows for a more detailed analysis of the liquidity constraint. 
The analysis suggests that the methodological issues have to be carefully taken into account. The estimation of a dynamic growth regression with panel data has the advantage of overcoming the two main drawbacks of the classical growth regression à la Barro: the omitted variable bias and the endogeneity of the right-hand side variables. However, the choice of the estimator is not easy, since there is not a first-best solution. The paper argues that the System-GMM could be taken as a benchmark, after having verified some conditions that should assure its superiority against the Arellano-Bond and the LSDV estimator. Nevertheless, GMM technique is developed for micro data and has asymptotic properties, so that the results should be taken with caution because of the finite sample and, thus, their robustness is checked using different estimators.

The empirical results of the growth equation confirm the basic conclusion of the augmented Solow model. With respect to the debt-growth nexus, the relationship is linear and negative, and there is not evidence of an inverse U-shaped curve. Debt service, instead, does not have a direct impact on GDP growth, even if it is found to crowd out investment. These results are confirmed using different debt indicators, estimating different specifications of the models, and considering different sub-samples. The semi-elasticity of GDP growth to the debt-toexports ratio is quite stable at $1.2-1.4$, meaning that a $10 \%$ increase in the debt ratio reduces the rate of per capita GDP growth by 0.12 percentage point. Furthermore, high debts do not lower significantly the investment level, but they reduce the quality and the efficiency of investment. This presumption is confirmed by the investment model, which points out the effectiveness of the liquidity constraint and the lack of an adverse effect of debt ratios on the investment level. This misallocation of resources, maybe due to short-termism, is consistent with "debt overhang".

The effects of high debt on investment and economic growth are much larger in the poorest countries than in the other developing countries, probably because in LICs, poor institutional quality and weak policies worsen the adverse effect that indebtedness has on economic performance.

Data for 52 LICs show that a debt reduction from a debt-to-export ratio of 300 to the HIPC threshold of 150 adds more than a percentage point to per capita GDP growth rate, while a $1 \%$ reduction in debt service raises the growth rate of GDP by another $0.1 \%$.

In sum, this paper underlines the great relevance that debt issues have in Low-Income countries and investigate the adverse effect that a large indebtedness has on the rate of economic growth, finding support for the liquidity constraint and the disincentive effects: debt service payments, debt overhang and the creation of an uncertain and unstable macroeconomic environment are a constraint to investment and growth. The investment level is reduced by debt service, while its efficiency is affected by high external debts, because of the instability that indebtedness generates.

As a consequence, what really matters for the debt-growth nexus is the liquidity constraint and the uncertainty that high debts create in the macroeconomic environment. Reducing debt service alone, even if it is effective, is no more than a form of aid and it is likely to fail the target of helping the world's poorest countries to have a foothold on the development ladder. Debt relief, instead, could be a way to start a new path of economic growth, because it reduce uncertainty and it could foster the development of sound institutions and the implementation of growth and market oriented policies, that are the main determinant of economic growth. Eventually, even if debt relief is proved to be effective in LICs, it should be included in the more general framework of foreign assistance, which relates to the issues of degree of conditionality and selectivity, and includes considerations of moral hazard and 
incentives, along with a careful analysis of alternative sources of financing and the risks due to a rising domestic debt in poor countries. 


\section{References}

Adam, C.S., 1998, "Implementing Small-Sample Bias Correction in Dynamic Panel Data Estimators using STATA”, mimeo, June 1998.

Agenor, Pierre-Richard, 2005, The Economics of Adjustment and Growth, Harvard University Press, Cambridge, Mass.

Anderson, T. W., and C. Hsiao, 1981, "Estimation of dynamic models with error components", Journal of American Statistical Association, Vol. 76, No. 375, pp. 598606.

Arellano, Manuel, and Stephen R. Bond, 1991, "Some Tests of Specification for Panel Data: Monte Carlo Evidence and an Application to Employment Equations", Review of Economic Studies, Vol. 58, pp. 277-297.

Arnone, Marco, Luca Bandiera and Andrea Presbitero, 2005, "External Debt Sustainability: A Critical Approach to the Policy Debate", draft World Bank Working Paper 2005, Washington DC.

Arnone, Marco, and Andrea F. Presbitero, 2005, "Sostenibilità e Riduzione del Debito Estero per i Paesi Poveri", Working Paper, Catholic University of Milan (Piacenza), February 2005.

Asiedu, Elizabeth, 2003, "Debt relief and institutional reform: a focus on Heavily Indebted Poor Countries", The Quarterly Review of Economics and Finance Vo. 43, pp. 614626.

Baltagi, Badi H., 1995, Econometric Analysis of Panel Data, John Wiley \& Sons, Chichester.

Birdsall, Nancy, and Brian Deese, 2002, "Beyond HIPC: Secure Sustainable Debt Relief for Poor Countries", Center for Global Development Working Paper, No. 44.

Blundell, Richard, and Stephen Bond, 1997, "Initial conditions and moment restrictions in dynamic panel data models", Journal of Econometrics, Vol. 87, pp. 115-143.

Blundell, Richard, Stephen Bond, and Frank Windmeijer, 2000, "Estimation in Dynamic Panel Data Models: Improving on the Performance of the Standard GMM Estimators", The Institute of Fiscal Studies Working Paper, No. 00/12.

Bond, Stephen, Anke Hoeffler, and Jonathan Temple, 2001, "GMM Estimation of Empirical Growth Models", mimeo, September 2001.

Bond, Stephen, Asli Leblebicioglu, and Fabio Schiantarelli, 2004, "Capital Accumulation and Growth: A New Look at the Empirical Evidence", Boston College Working Paper in Economics, No. 591. 
Bruno, Giovanni S.F., 2004, "Approximating the Bias of the LSDV Estimator for Dynamic Unbalanced Panel Data Models", Bocconi University Working Paper EEA 2004-1

2005, "XTLSDVC: Stata module to estimate bias corrected LSDV dynamic panel data models", downloadable at http://ideas.repec.org, April 2005

Burnside, Craig and David Dollar, 2000, "Aid, Policies and Growth", American Economic Review, Vol. 90, No. 4, pp. 847-68, September 2000.

Chowdhury, Abdur R., 2004, "External Debt, Growth and the HIPC Initiative: Is the Country Choice Too Narrow?", chapter 8 in Debt Relief for Poor Countries, ed. by Addison, Hansen and Tarp.

Clements, Benedict, Rina Bhattacharya, and Toan Q. Nguyen, 2004, "External Debt, Public Investment, and Growth in Low-Income Countries", IMF Working Paper No. 03/249.

Cline, William, 1995, International Debt Reexamined, (Washington D.C: Institute for International Economics).

Cohen, Daniel, 1993, "Low Investment and Large LCD Debt in the 1980's", The American Economic Review, Vol. 83, No. 3.

Cordella, Tito, Luca A. Ricci, and Marta Ruiz-Arranz, 2005, “Deconstructing HIPCs' Debt Overhang", mimeo, International Monetary Fund, April 2005.

Davidson, Russel, and James G. MacKinnon, 2004, Econometric Theory and Methods, Oxford University Press, Oxford.

Easterly, William, 2001, The Elusive Quest for Growth: Economists Adventures and Misadventure in the Tropics, (Cambridge, Mass: The MIT Press).

----------2002, “How Did Heavily Indebted Poor Countries Become Heavily Indebted? Reviewing Two Decades of Debt Relief", World Development, Vol. 30, No. 10, pp. 1677-1696.

Easterly, William, and Klaus Schmidt-Hebbel, 1991, "The Macroeconomics of Public Sector Deficits”, World Bank Country Economic Department Working Paper, No. 775.

Easterly, William, Norman Loayza, and Peter Montiel, 1997, "Has Latin America's postreform growth been disappointing?", Journal of International Economics, Vol. 43, pp. 287-311.

Elbadawi, Ibrahim A., Benno J. Ndulu, and Njuguna Ndung'u, 1999, "Debt Overhang and Economic Growth in Sub-Saharan Africa", chapter 5 in External Finance for LowIncome Countries, ed. by Iqbal, Zubair, and Ravi Kanbur (Washington D.C: IMF Institute).

Erixon, Fredrik, 2005, “Aid and Development: Will it Work This Time?”, International Policy Network, June 2005. 
Gupta, Sanjeev, Benedict Clements, Emanuele Baldacci, and Carlos Mulas-Granados, 2005, "Fiscal policy, expenditure composition, and growth in low-income countries", Journal of International Money and Finance, Vol. 24, pp. 441-463.

Gunning, Jan W., and Richard Mash, 1998, "Fiscal Implications of Debt and Debt Relief: Issues Paper". Mimeo.

Hansen, Henrik, 2004, "The Impact of External Aid and External Debt on Growth and Investment". chapter 7 in Debt Relieffor Poor Countries, ed. by Addison, Hansen and Tarp.

Hoeffler, Anke E., 2002, "The augmented Solow model and the African growth debate", Oxford Bulletin of Economics and Statistics, Vol. 64, No. 2, pp. 135-158.

Imbs, Jean, and Romain Ranciere, 2005, "The Overhang Hangover", World Bank Policy Research Working Paper, No. 3673, August 2005.

Judson, Ruth A., and Ann L. Owen, 1999, "Estimating dynamic panel data models: a guide for macroeconomists", Economic Letters, No. 65, pp. 9-15.

Kiviet, Jan F., 1995, "On bias, inconsistency, and efficiency of various estimators in dynamic panel data models", Journal of Econometrics, Vol. 68, pp. 53-78.

Kraay, Aart, and Vikram Nehru, 2004, "When Is External Debt Sustainable?" World Bank Policy Research Working Paper, No. 3200.

Krugman, Paul, 1988, "Financing vs. Forgiving a Debt Overhang", Journal of Development Economics, No. 29, pp. 253-268.

Moss, Todd J., and Hanley S. Chiang, 2003, The Other Costs of High Debt in Poor Countries: Growth, Policy Dynamics, and Institutions", Issue Paper on Debt Sustainability, Center for Global Development, Washington DC, August 2003.

Nkurunziza, Janvier D., and Robert H. Bates, 2003, "Political Institutions and Economic Growth in Africa", CSAE Working Paper, No. 2003-03.

Pattillo, Catherine, Helene Poirson, and Luca Ricci, 2002, "External Debt and Growth", IMF Working Paper, No. 02/69.

--------2004, "What Are the Channels Through Which External Debt Affects Growth?", IMF Working Paper, No. 04/15.

Presbitero, Andrea F., 2005, "The debt-growth nexus: an empirical analysis", mimeo, downloadable at: $\quad$ www.unicatt.it/convegno/open_economy/Allegati/debtgrowth presbitero.pdf 
Roodman, David, 2003, "XTABOND2: Stata module to extend xtabond dynamic panel data estimator," Statistical Software Components S435901, Boston College Department of Economics, revised 22 Apr 2005.

Sachs, Jeffrey D., 1989, "The Debt Overhang of Developing Countries". In Debt, Stabilization and Development, by Calvo, Guillermo A., Ronald Findlay, Pentti Kouri, and Jorge Braga de Macedo, (Oxford: Basil Blackwell).

Serven, Luis, 1996, "Irreversibility, Uncertainty and Private Investment: Analytical Issues and Some Lessons for Africa", The World Bank, Mimeo, December 1996. 
Annex A: Descriptive Statistics and Regression Tables

Table A: Descriptive Statistics

\begin{tabular}{|l|r|r|r|}
\hline Variable & Observations & Mean & Std. Dev. \\
\hline & & & \\
per capita GDP growth rate & 2743 & 0.789 & 7.375 \\
GDP per capita , PPP & 2789 & 3825.966 & 3567.368 \\
Population growth rate & 3585 & 1.957 & 1.630 \\
Openness (M+X)/GDP] & 2660 & 78.030 & 43.785 \\
Budget Balance (\% of GDP) & 1900 & -3.349 & 5.451 \\
M2 (\% of GDP) & 2752 & 36.014 & 31.461 \\
Investment (\% of GDP) & 2830 & 21.743 & 9.266 \\
Gross Primary enrolment rate & 1717 & 92.892 & 24.437 \\
Inflation (Consumer price, annual \%) & 2514 & 75.029 & 666.759 \\
Revenues (\% of GDP) & 1905 & 19.475 & 12.318 \\
Domestic credit (\% of GDP) & 2724 & 28.128 & 24.080 \\
Aid (ODA as a \% of GDP) & 2916 & 9.433 & 14.242 \\
Terms of trade & 2012 & 109.974 & 39.955 \\
Total Debt Service (\% of GDP) & 2694 & 5.370 & 4.687 \\
Total Debt Service (\% of exports) & 2517 & 19.721 & 15.302 \\
NPV Debt/Exports & 1069 & 400.260 & 639.280 \\
NPV Debt/GDP & 1204 & 82.915 & 120.808 \\
Debt/Exports & 2517 & 333.689 & 501.205 \\
Debt/GDP & 2694 & 79.274 & 97.550 \\
\hline
\end{tabular}




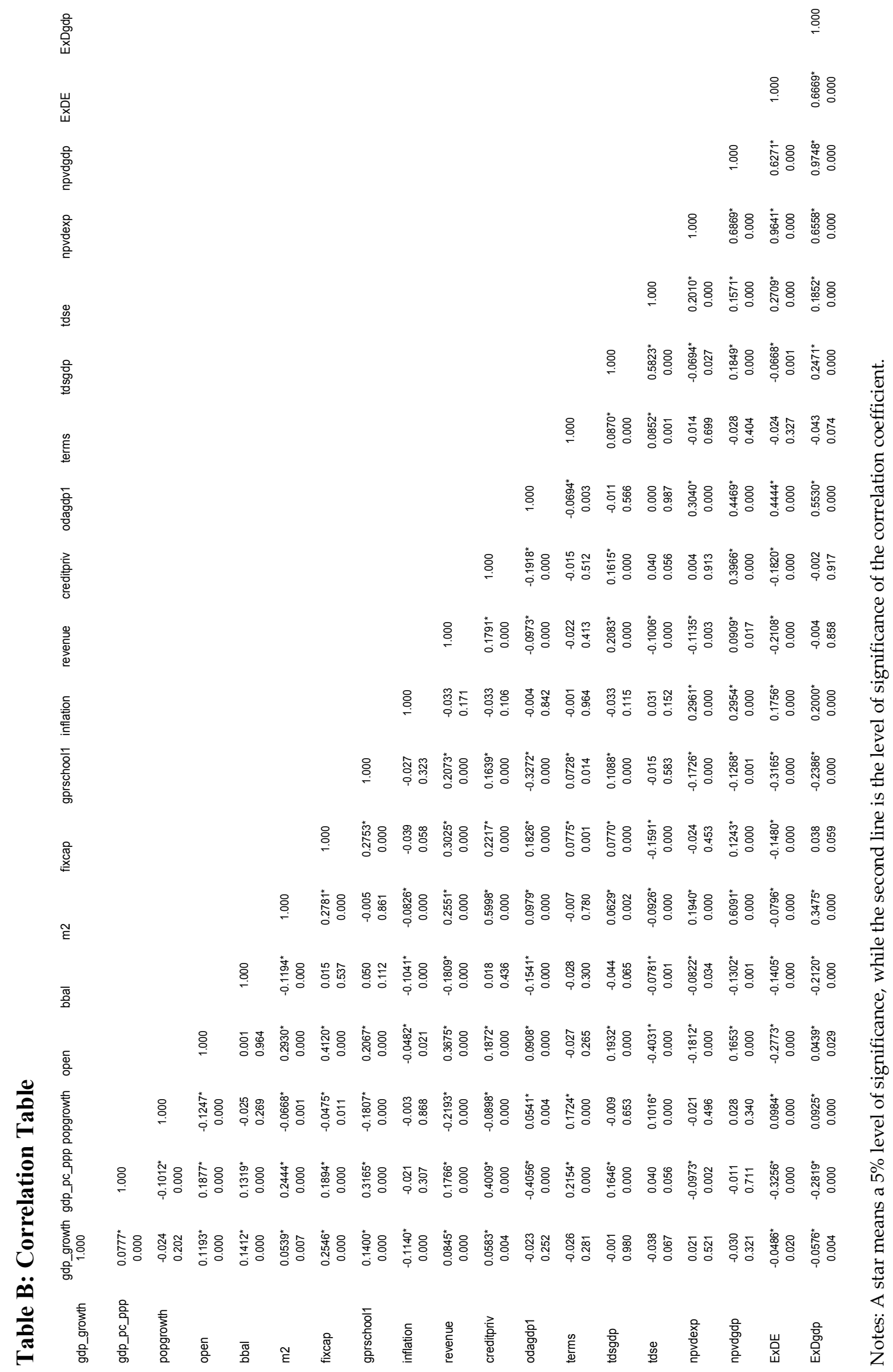




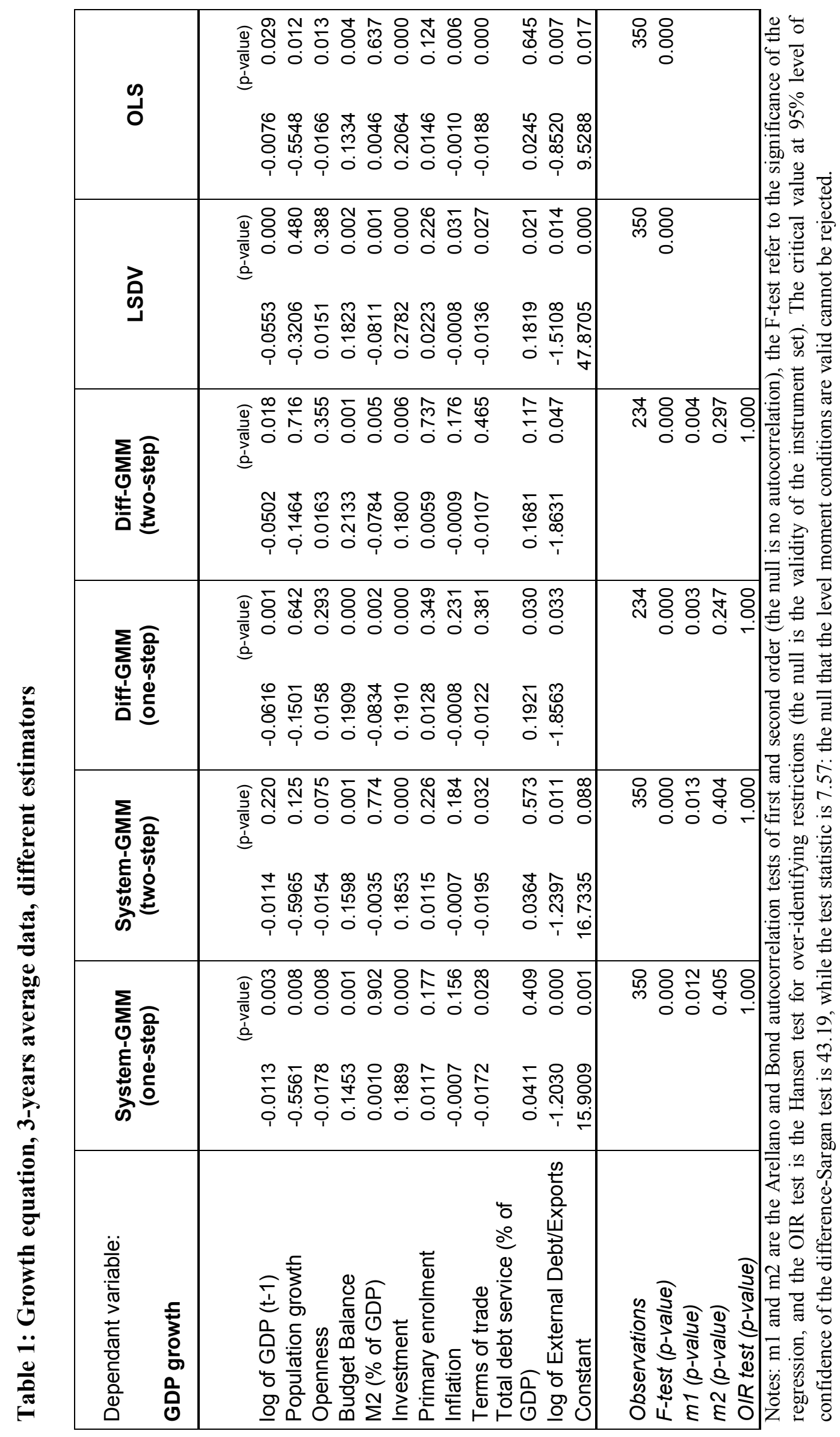




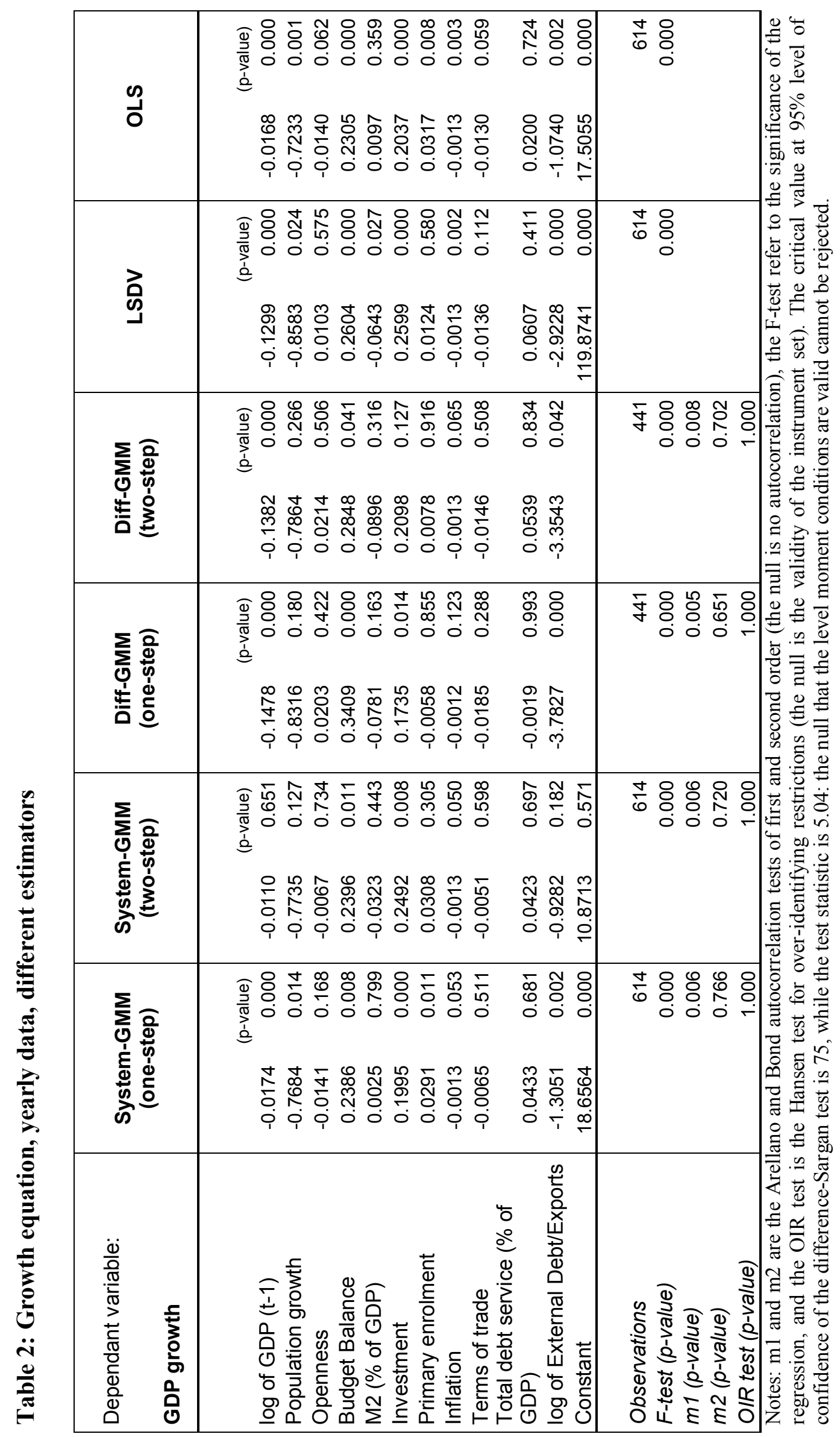




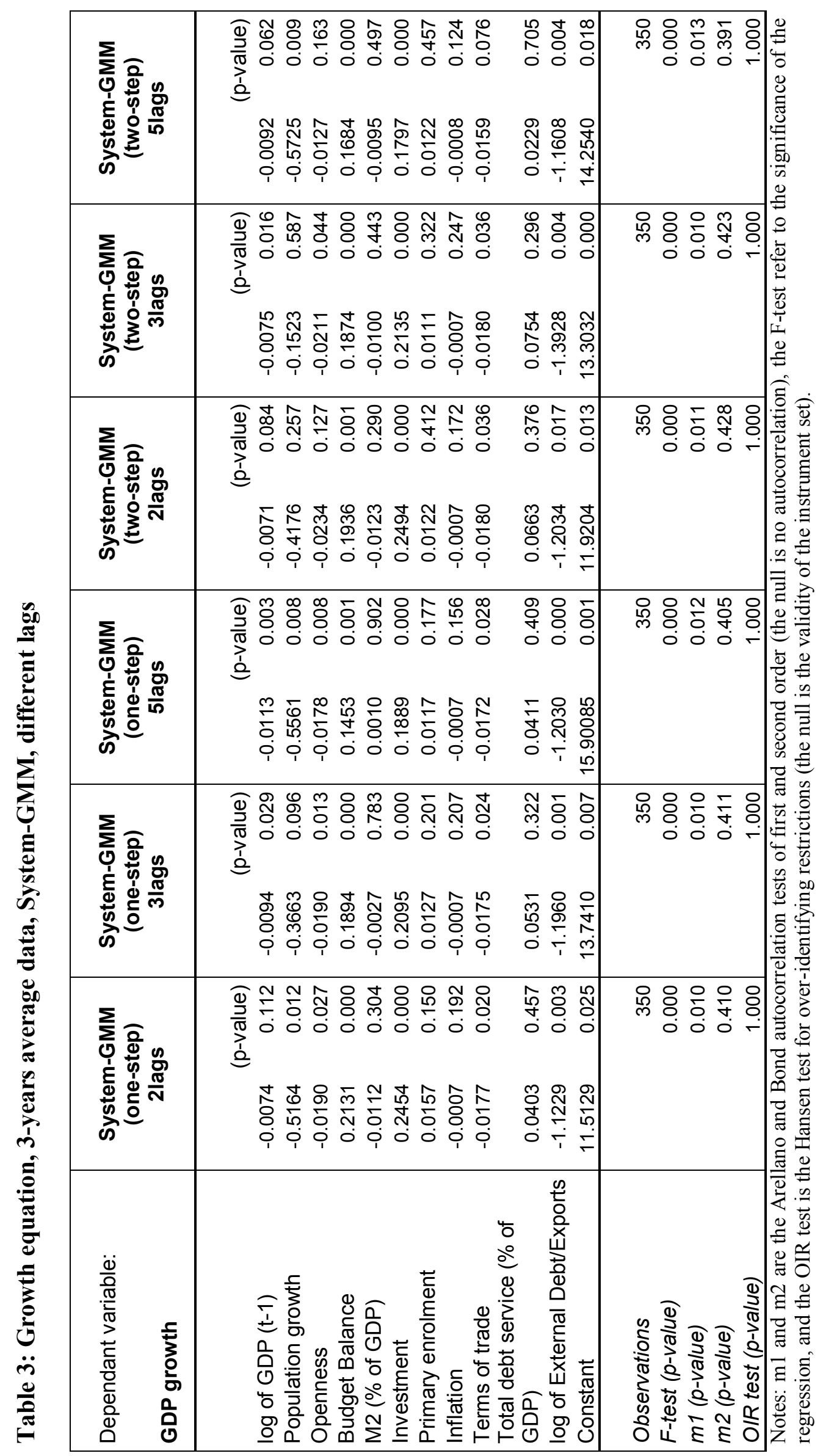




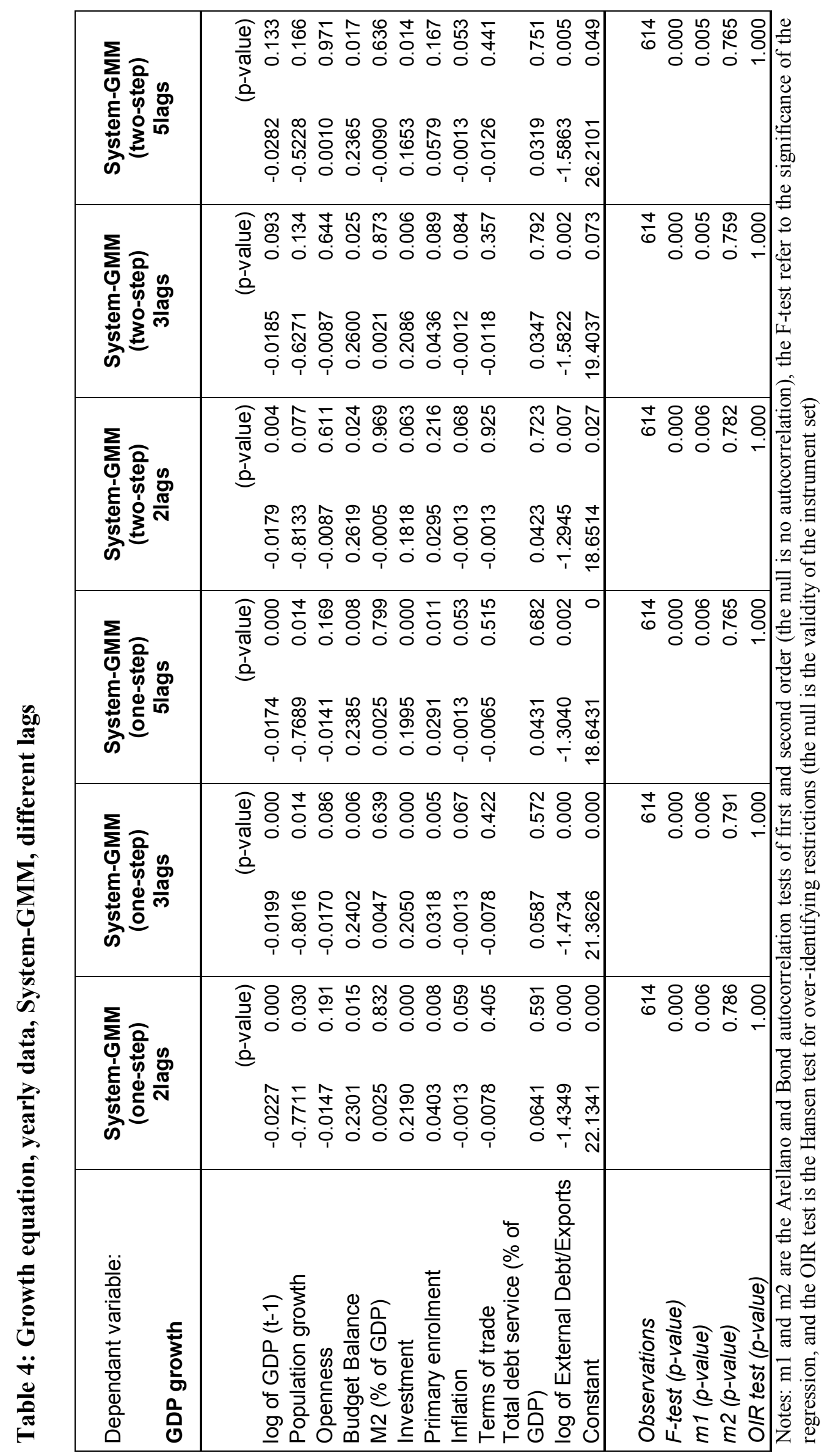




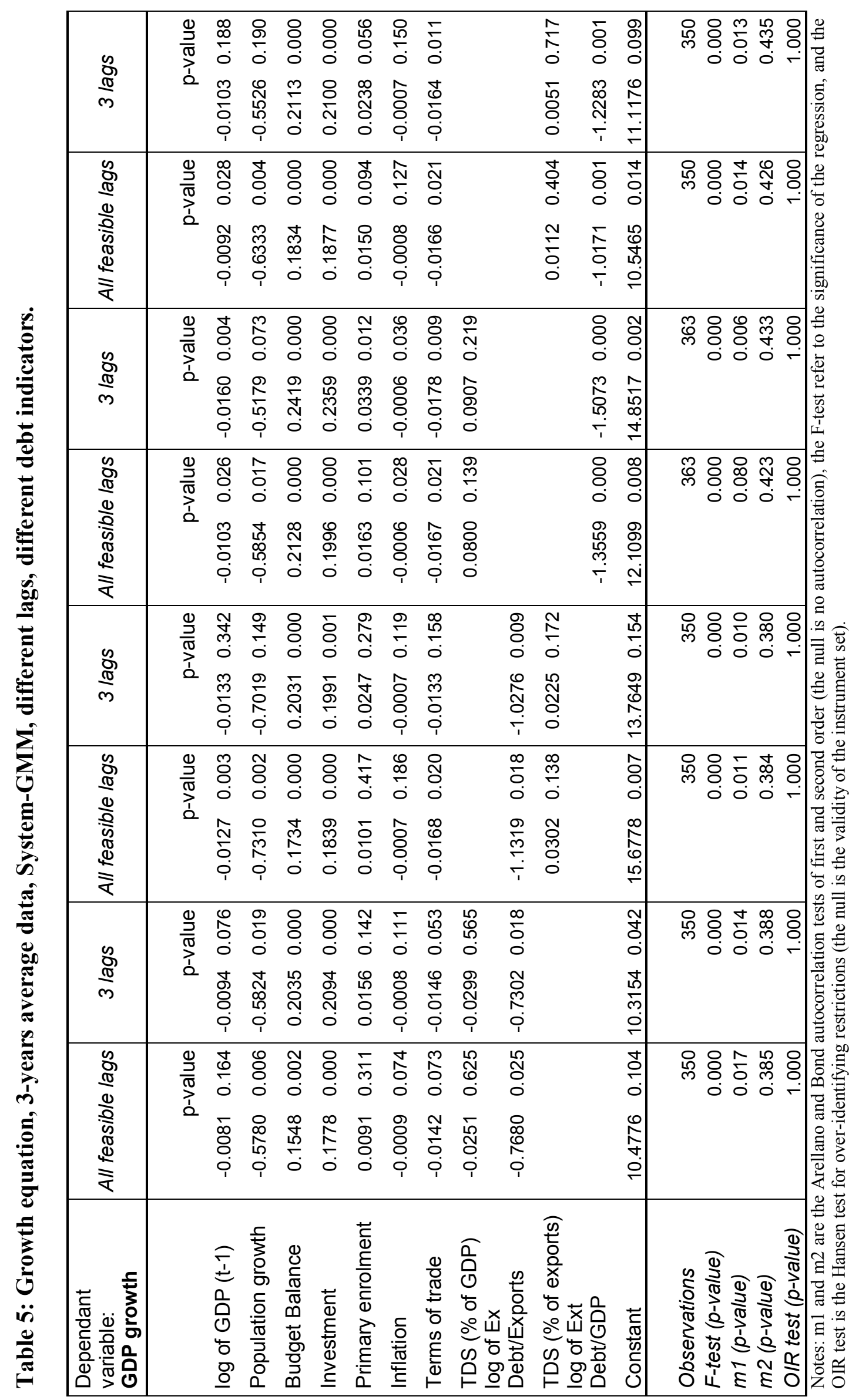




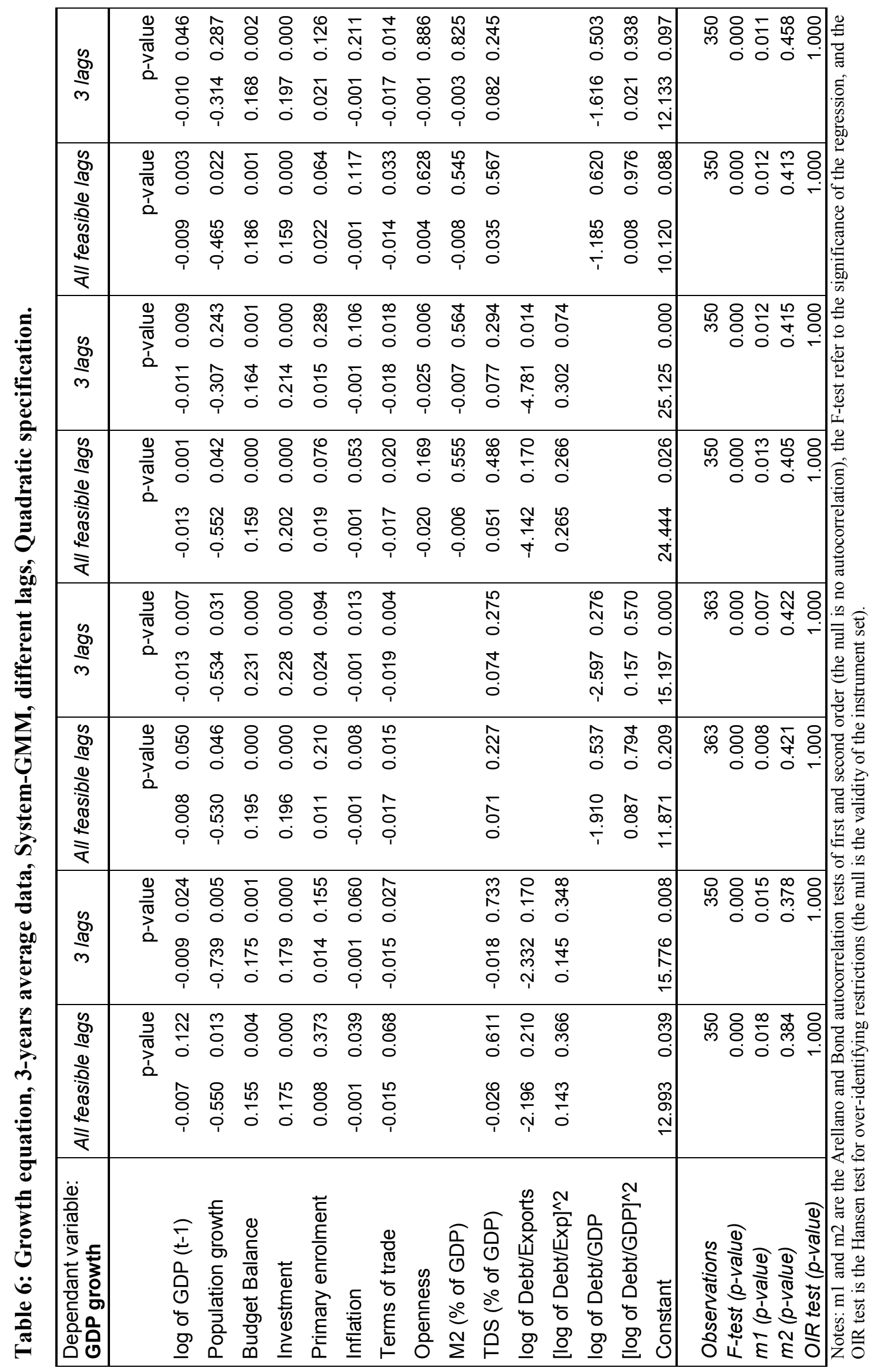




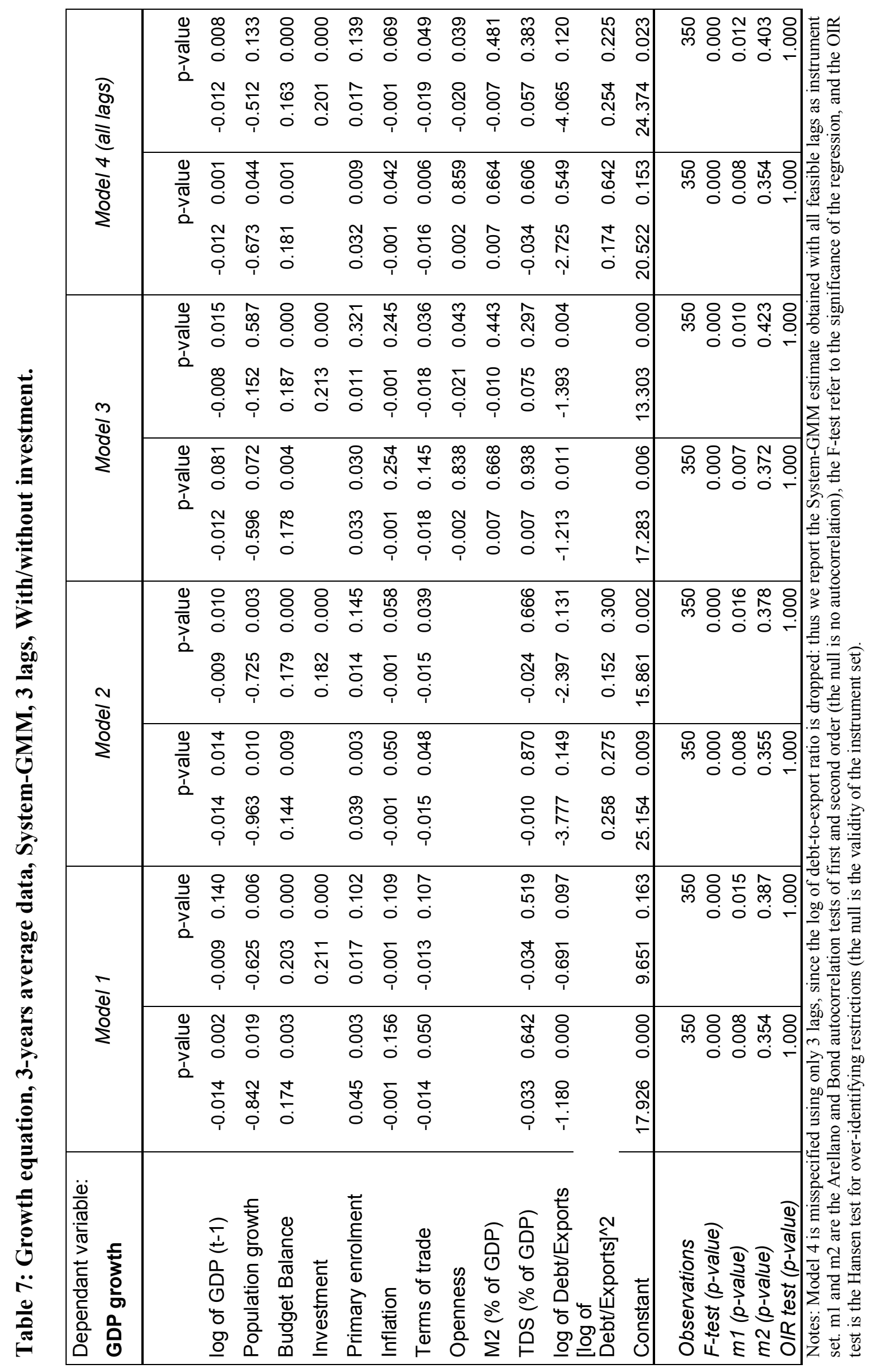




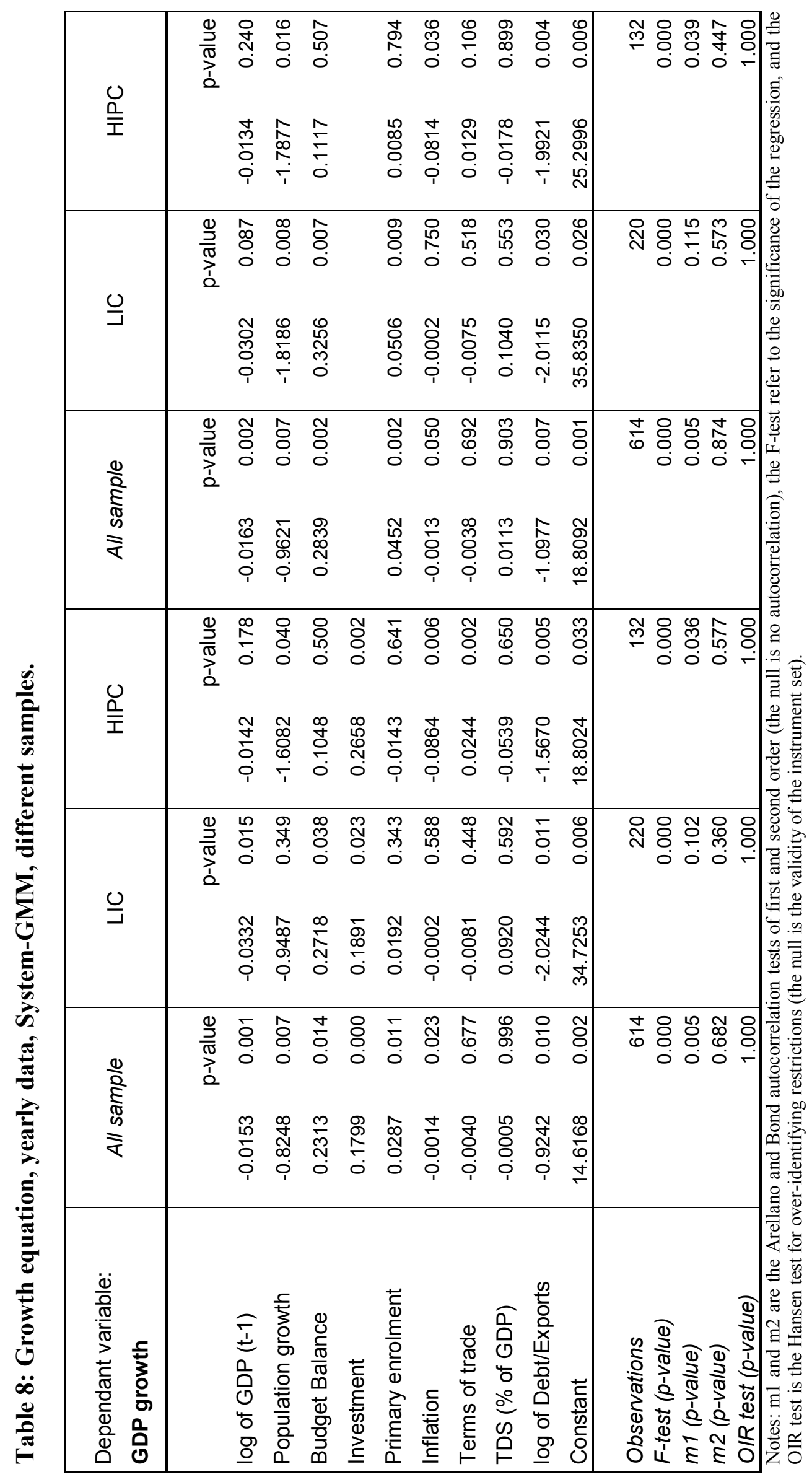




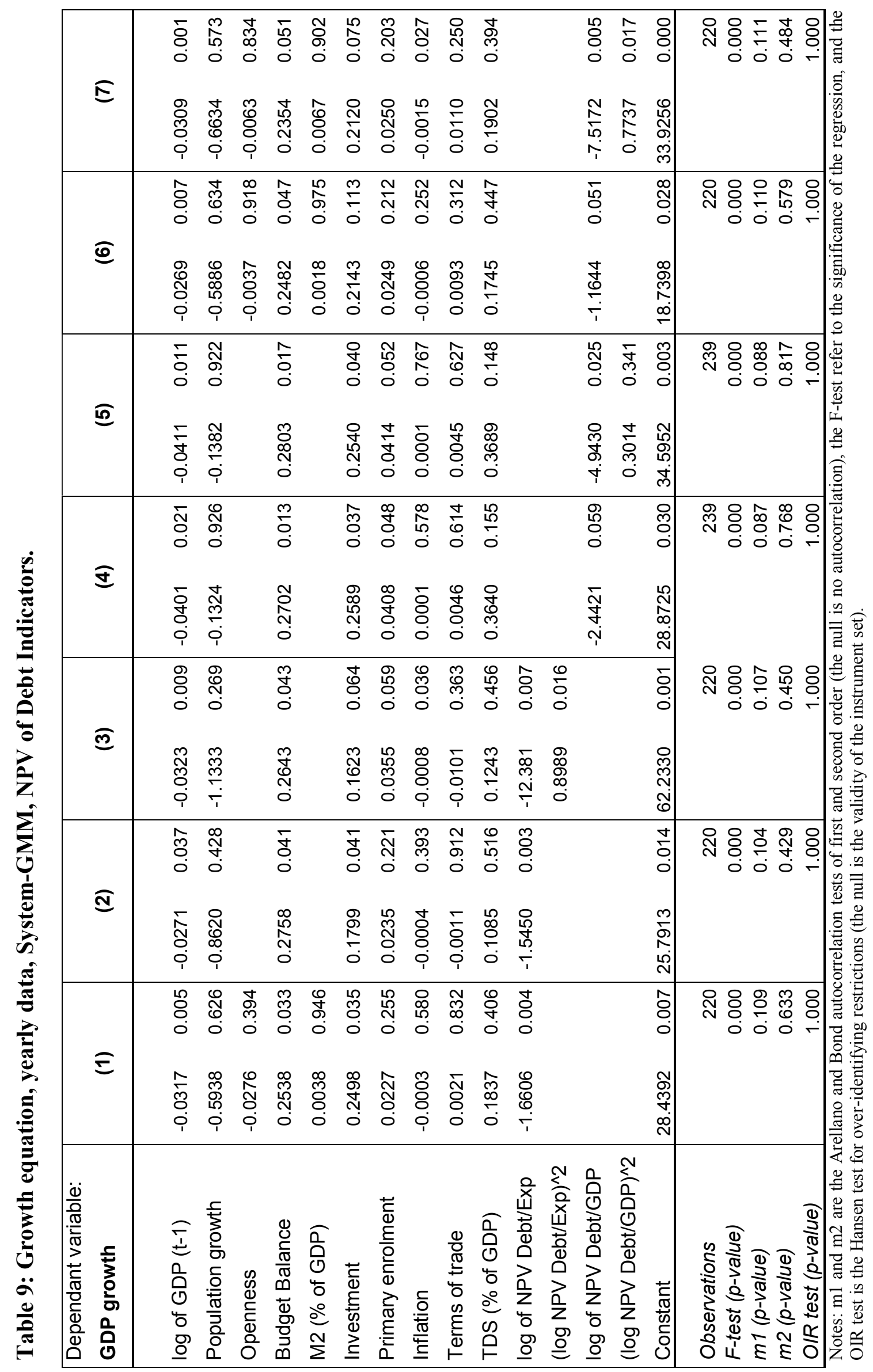




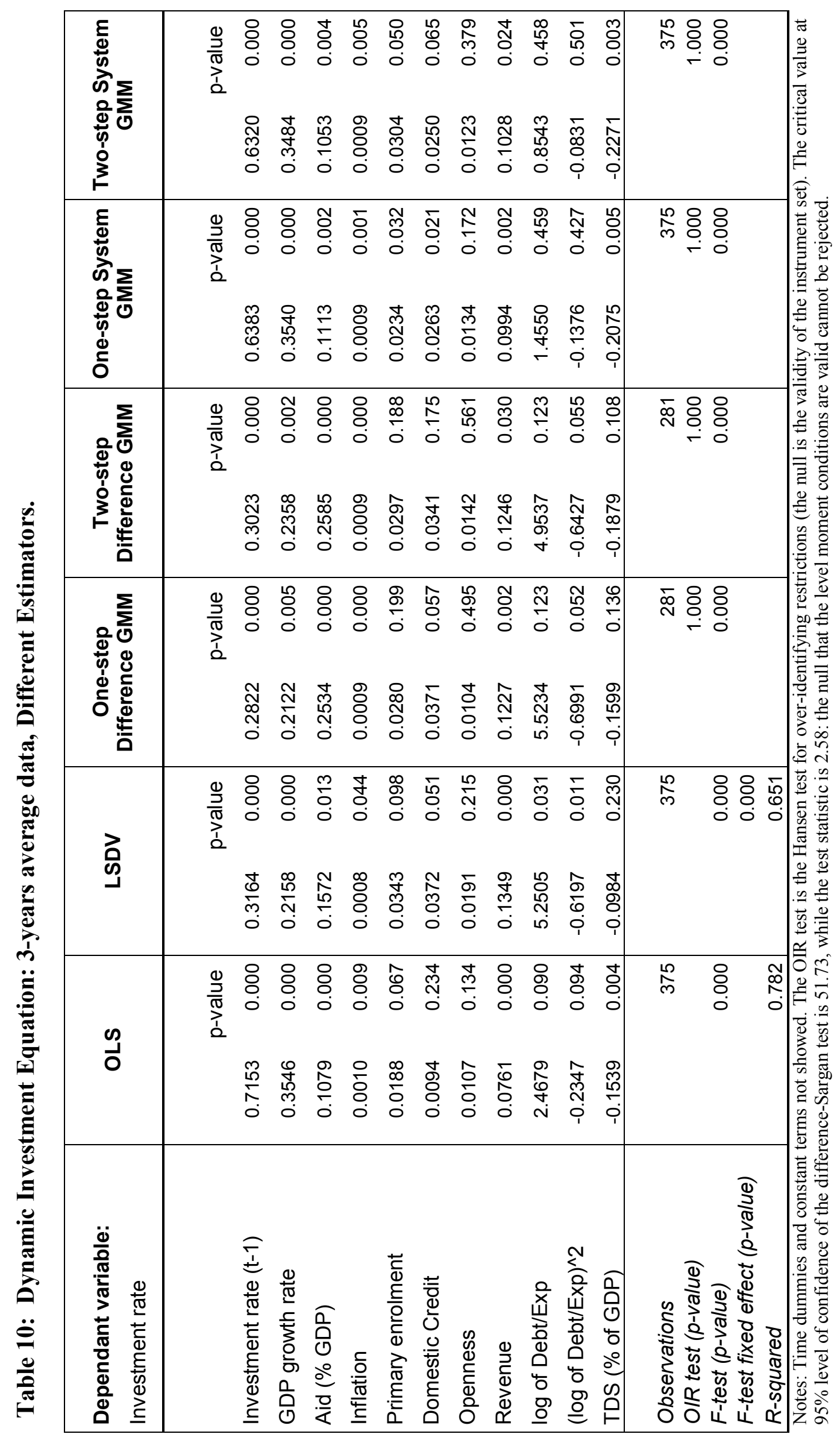




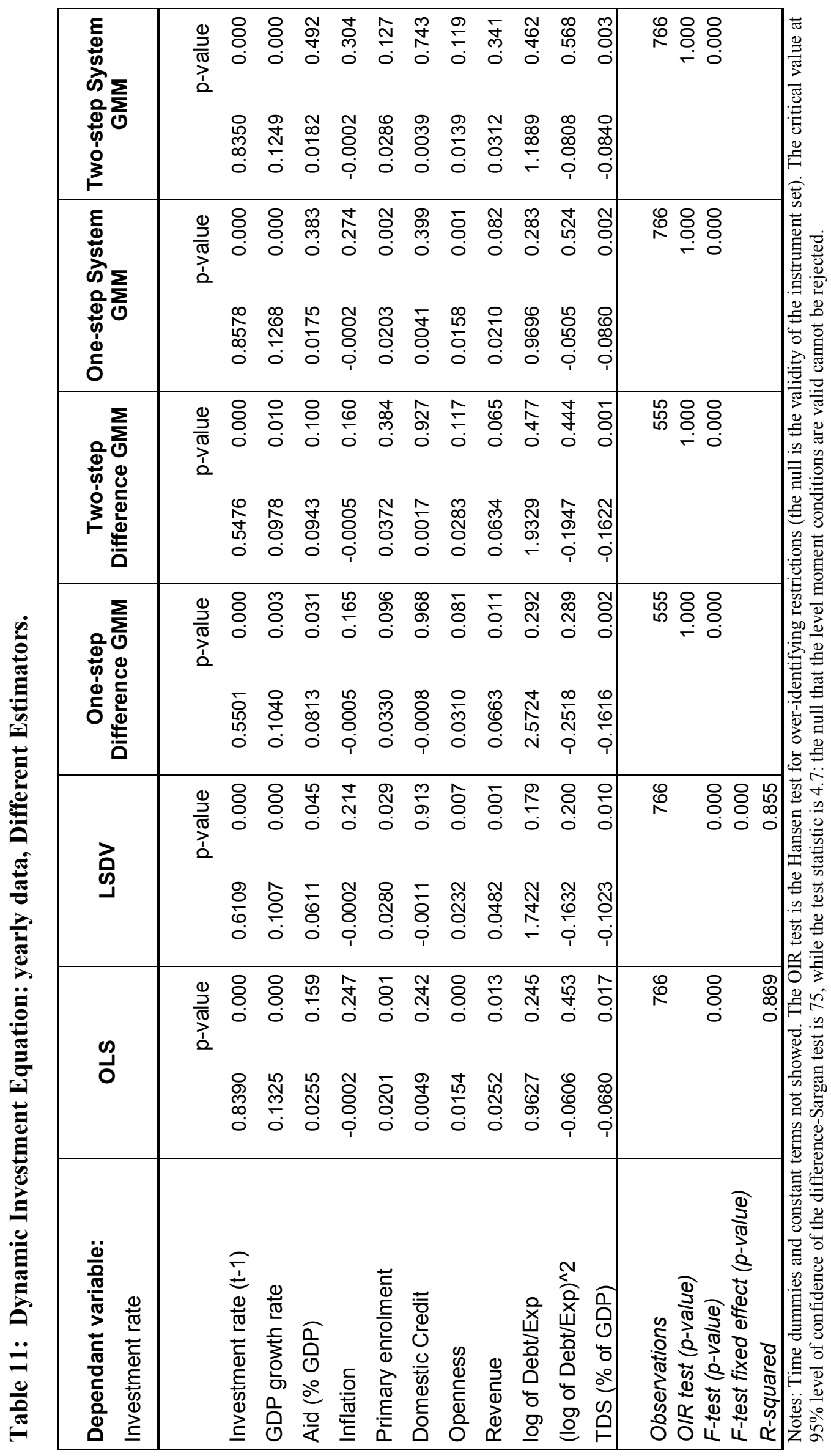




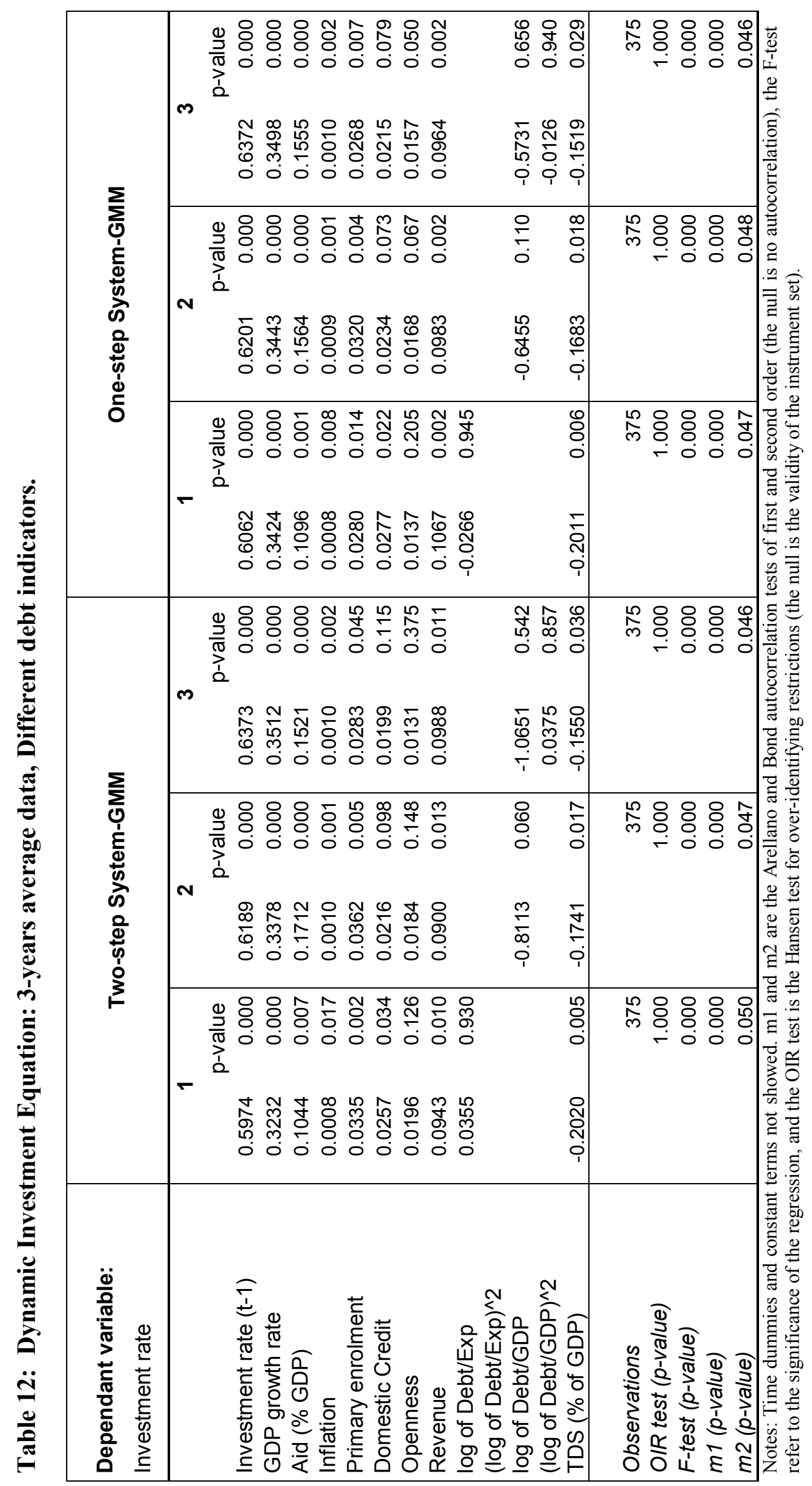




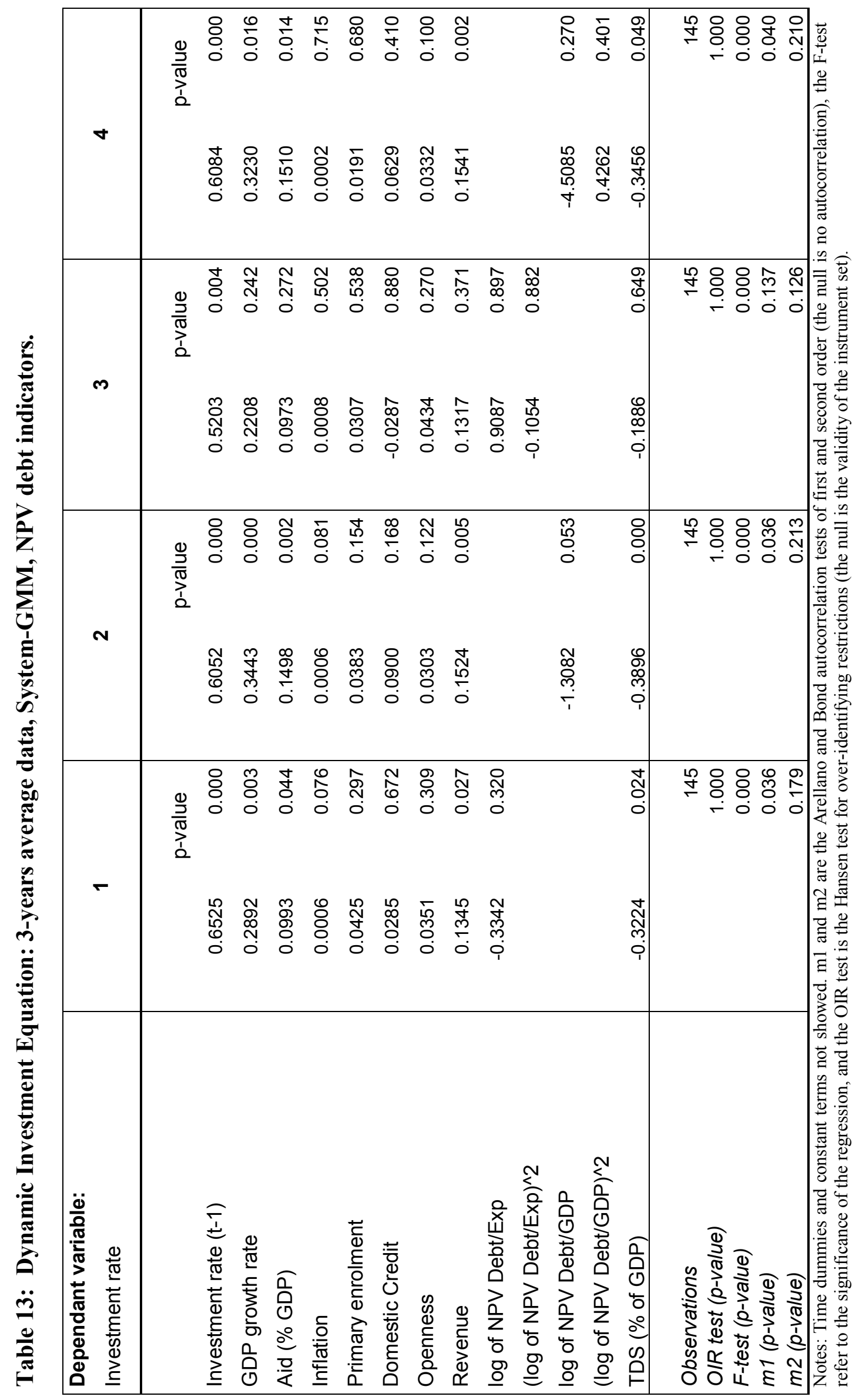




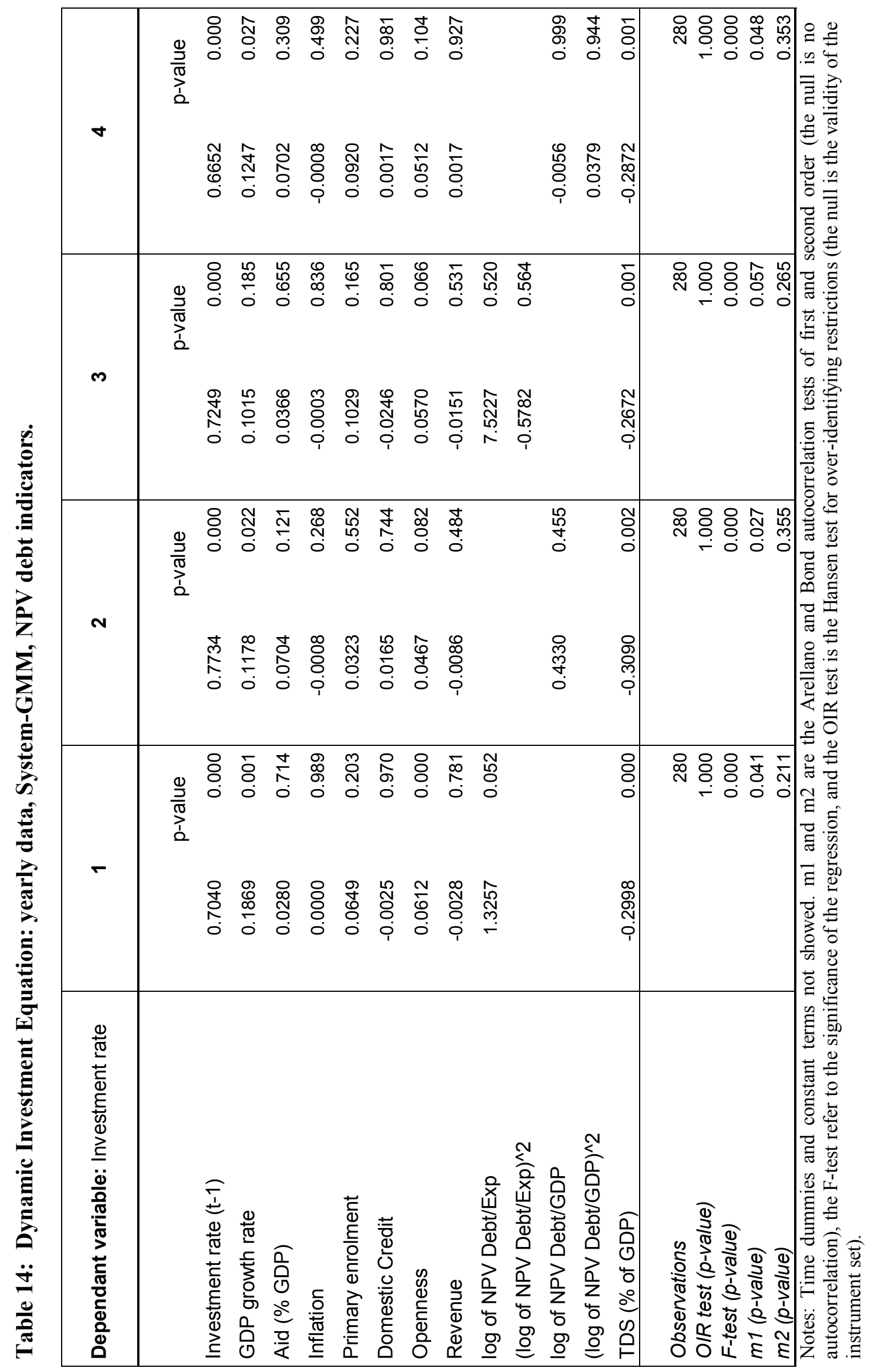

